\title{
Reading the Stars at the Ottoman Court: Bāyezīd II (r. 886/1481-918/1512) and His Celestial Interests
}

\author{
Ahmet Tunç Şen \\ Columbia University \\ ats2171@columbia.edu
}

\begin{abstract}
This study seeks to determine the extent of the patronage of the science of the stars ('ilm al-nuğūm) at the court of the eighth Ottoman sultan Bāyezīd II (r. 886/1481918/1512). Throughout the medieval and early modern Islamicate world munağğims (astronomer-astrologers) offered rulers their expertise in calculating heavenly configurations and interpreting them with a view to predicting future events; here the Ottoman polity is no exception. In the case of Bāyezìd II, however, the sheer number of munağğims employed and texts and instruments commissioned by or dedicated to the sultan unequivocally singles him out and makes it possible to further argue that his deliberate attempt to personally study and cultivate the science of the stars was inextricably related to the broader political, ideological, and cultural agendas at the time. The first part of the article provides statistical evidence on the exceptional nature of Bāyezīd's patronization of the science of the stars based upon a number of archival documents, taqwims (annual almanac-prognostications) and related texts presented to the sultan. Here a number of key munağğims active at his court will also
\end{abstract}

* The research for this article, based on my dissertation chapter, was made possible by the generous grants from the American Research Institute in Turkey and the Social Science Research Council. I would like to thank Zeynep Çelik Atbaş from the Topkapı Palace Museum Library, Buket Özdemir from the Archives of the Topkapı Palace Museum, Tahsin Tahaoğlu from the Boğaziçi University Kandilli University Library, and the staff of the Süleymaniye Library for making manuscripts and archival documents available. A special thanks to Bill Walsh for proofreading the text and sharing with me his valuable suggestions. I am also thankful to Christopher Markiewicz, Cornell H. Fleischer, Eva Orthmann, Matthew MelvinKoushki, Mohamad Ballan, and the anonymous referees for their insightful comments on different versions of this study. Needless to say, all shortcomings and errors remain my sole responsibility. 
be introduced. The second part focuses upon Bāyezīd's own learned interests and intellectual aspirations, and examine the celestial inquiries of the sultan in light of a few curious archival reports, textual evidence from surviving manuscripts, and testimonies of his contemporaries.

\section{Keywords}

Ottomans, Bāyezīd II, science, astronomy, astrology, alchemy, ‘ilm al-nuğūm, munağğim, taqwìm, zĭğ

\section{Résumé}

Cette étude vise à apprécier l'étendue du mécénat sur la science des étoiles ('ilm al-nuğūm) à la cour du huitième sultan ottoman Bāyezīd II (r. 886/1481-918/1512). Dans tout le monde islamique médiéval et prémoderne, les munağǧims (astronomesastrologues) offrirent aux gouvernants leur expertise pour calculer les configurations célestes et les interpréter en vue de prédire les événements futurs. De ce point de vue, la politique ottomane ne fait pas exception. Cependant, dans le cas de Bāyezīd II, le nombre incroyable de munağǧims employés, de textes et d'instruments commandés par ou dédicacé pour le sultan le distinguent clairement et permettent d'avancer que sa tentative délibérée d'étudier personnellement et de cultiver la science des étoiles était inextricablement liée à un programme politique, idéologique et culturel plus large à l'époque. La première partie de l'article donne les preuves statistiques de la nature exceptionnelle du mécénat de Bāyezīd sur la science des étoiles en s'appuyant sur un certain nombre de documents d'archives, de taqwìms (almanachs-prognostics annuels) et de textes apparentés présentés au sultan. Un certain nombre de munağğims importants actifs à sa cour y seront également présentés. La deuxième partie se concentre sur les propres intérêts savants et les aspirations intellectuelles de Bāyezīd et examine les aspirations célestes du sultan à la lumière de quelques curieux rapports d'archives, de preuves textuelles provenant de manuscrits et de témoignages de ses contemporains.

\section{Mots clefs}

Ottomans, Bāyezīd II, science, astronomie, astrologie, alchimie, 'ilm al-nuğūm, munağğim, taqwìm, zĭğ 


\section{Introduction}

In šawwāl 894/September 1489, a certain Šukr Allāh Širwānī (d. after 910/15041505) presented the Ottoman sultan Bāyezīd II a compendium of sciences entitled Riyā al al-qulüb, in which he cataloged eight disciplines ranging from Sufism and 'ilm al-hay'a (lit. the science of the configuration of the heavens) to physiognomy and 'ilm al-nuğüm (lit. the science of the stars). ${ }^{1}$ In the section where he discusses the true meaning and benefit of 'ilm al-nuğùm, Širwānī writes:

There is no discipline, save the religious sciences, nobler than 'ilm alnuğüm [...]. Rulers and sultans have need of it because incidents like earthquake, flood, war, famine, plague, and others occur in the sublunary world due to the influence of the conjunctions, eclipses, and various planetary aspects. If one is knowledgeable in this science and closely tracks these celestial phenomena, one may hope to be secure from all harm. ${ }^{2}$

Širwānī remained a presence at Bāyezīd's court until as late as 910/1504-1505. In addition to his encyclopedic work, he also presented the sultan an astrolabe of his own original construction. ${ }^{3}$ In this regard it is no surprise to find Širwānī insisting on the virtues of the science of the stars in his compendium. However, Širwānī was not the only figure at the time who saw 'ilm al-nuğùm as

1 Although Šukr Allāh Širwānī is usually considered to be one of the physicians at the court of Mehmed II (r. 848/1444-850/1446, 855/1451-886/1481), the author of this text would seem to be another Šukrullāh from Širwān. First of all, the author does not include medicine in his compendium; it is quite unprecedented for an author not to mention his own craft. Secondly, Ṭāšköprüzāde (d. 968/1561) says in his biographical dictionary that the physician Šukr Allāh Širwānī who came to the Ottoman lands at the time of Murād II (r. 824/1421848/1444, 850/1446-855/1451) passed away during the reign of Mehmed II, long before Riyāe al-qulūb was composed. See Țāšköprüzāde, al-Šaqā’iq al-nu'māniyya fí 'ulamā’ al-dawlat al-'uțmāniyya, Beirut, Dār al-kitāb al-'arabī, 1395/1975, p. 135.

2 MS Istanbul, Süleymaniye, Ayasofya, 4024, f. 62b: ba'd az 'ulūm-i dīn̄ hīc 'ilm a'lā az 'ilm-i nuğūm nīst [...] wa-muhtāğ ilayhi mulūk wa-salāṭin-ast čūn bi-wāsița-i ta'țîr-i qirānāt wa-kusūfāt wa-sāirr-i hạlāt-i kawākib dar 'ālam-i kawn wa-fașād waqāyi'wa-zalāzil wa-țūfānāt wa-muḥārabāt wa-qahț wa-wabā wa-amțāl-i ān wāqi mì-šawad. Agar kasī ìn 'ilm rā dānad wa-ān ḥālāt-rā dar yābad wa-ríāyat nimāyad umìd ki az āfāt sālim mānad.

3 David King, "Two Astrolabes for the Ottoman Sultan Bayezit II," in Essays in Honour of Ekmeleddin İhsanoğlu, ed. Mustafa Kaçar and Zeynep Durukal Abuhusayn, Istanbul, Ircica ("Studies and sources on the history of Islamic civilisation series", 13), 2006, I, p. 439-459. 
a noble inquiry. Many contemporary and near-contemporary authors of zĭğs (astronomical handbooks of tables), taqwims (annual almanac-prognostications), and treatises on various astronomical instruments are at pains to highlight this point in their texts.

There is an established conviction in the current historiography of science in the Islamic context, exemplified especially in the works of George Saliba, that from the third/ninth century onwards a clear distinction emerged within the discipline of 'ilm al-nuğum, ushering in the rise of the 'ilm al-hay'a (which is often identified as "astronomy" proper) and 'ilm ậkām al-nuğūm (which means the science of the decrees of the stars and is established as "astrology"). ${ }^{4}$ According to this interpretation, the separation between the two in terms of both terminology and subject matter was consolidated and principally recognized by later generations of Muslim scholars who almost always appreciated the former while frowning upon the latter. However, as the work of Širwānī and many other treatises that I will attempt to touch upon below indicate, the boundaries among disciplines, particularly among the branches that deal with the practical application of the celestial knowledge, were not as strict as this model supposes, at least in works from the late-medieval and early-modern Turko-Persian cultural zone. ${ }^{5}$ For instance, many examples of the ziğ literature are now usually considered to have served purely astronomical and mathematical purposes as state-of-the art mathematical and astronomical works of their time. ${ }^{6}$ However, most of the extant ziğg from the period, such as the Zĭg $-i$ $\bar{I} l h \bar{a} n \bar{\imath}$ (the Ilkhanid tables), prepared as part of the incomplete observational

4 George Saliba, "Astronomy and Astrology in Medieval Arabic Thought," in Les doctrines de la science de l'antiquité à l'âge classique, ed. Roshdi Rashed and Joël Biard, Leuven, Peeters ("Ancient and classical sciences and philosophy"), 1999, p. 131-164; id., "Islamic Astronomy in Context: Attacks on Astrology and the Rise of the Hay'a Tradition," Bulletin of the Royal Institute for Inter-Faith Studies, 4/1 (2002), p. 25-46.

5 For a supporting critique see Matthew Melvin-Koushki, "Powers of One: The Mathematicalization of the Occult Sciences in the High Persianate Tradition," Intellectual History of the Islamicate World, 5/1 (2017), p. 127-199, esp. p. 179-184.

6 Edward S. Kennedy, "A Survey of Islamic Astronomical Tables," Transactions of the American Philosophical Society, 46/2 (1956), p. 123-177; David A. King and Julio Samsó (with a contribution by Bernard R. Goldstein), "Astronomical Handbooks and Tables from the Islamic World (750-1900): An Interim Report," Suhayl, 2 (2001), p. 9-105. The authors already underline that the ziğs could be primarily used to cast horoscopes but also add "there is precious little evidence how these works were used in practice." For the mathematical properties of ziğs also see Benno van Dalen's collection of articles: Benno van Dalen, Islamic Astronomical Tables: Mathematical Analysis and Historical Investigation, Farnham-Burlington, Ashgate Variorum (“Collected studies series", 1040), 2013. 
program at the Maragha Observatory, or the Zïğ-i Ulug Beg (Ulug Beg's Tables), produced at the Samarkand Observatory, include large sections and tables essential for astrological calculations. ${ }^{7}$ In fact, the ziğ was an indispensable item in a munağğim's paraphernalia as it equipped the munağğim with the required data to calculate accurately the celestial configuration at a certain moment before extrapolating astrological interpretations. ${ }^{8}$ For example, in his Zì̆ğ-i $\bar{l} h h \bar{a} n \bar{\imath}$ Nașīr al-Dīn al-Ṭūìi (d. 672/1274), upon introducing his patrons and peers who helped him establish the Maragha Observatory and run the observational program, straightforwardly indicates the importance of his ziğ for astrological applications, saying that it is his hope that munağğims will benefit from his calculations when composing their yearly horoscopes and nativities. Al-Ṭūsī also highlights the importance of determining the stellar positions with greater accuracy in order to have foreknowledge about plagues, battles, or the length of any individual's life. ${ }^{9}$ In addition to ziğgs, many books on astronomical instruments, especially on astrolabes - which were primarily employed, among other purposes, as a computing device to map out the celestial configuration at a particular time for a given locality—also have individual chapters on how to determine the ascendant $\left(t+a \bar{l} i^{i}\right)$ and other astrological houses, information crucial for casting horoscopes or preparing annual astrological predictions. ${ }^{10} \mathrm{It}$ is therefore important that we focus more upon how certain types of knowledge

Especially the fourth chapter of the Zïğ-i Ulug Beg (Maqāla-i čahārum dar bāqü-i a'māl-i nuğummì) is dedicated entirely to the techniques used in horoscopic astrology, including namūdārāt, firdārāt, or tasyīrāt. In fact, the tables given in the second chapter (Maqāla-i duwum dar ma'rifat-i awqāt wa-țālici har waqt) as well as the third one (Maqāla-i siwum dar ma'rifat-i rawish-i sitāragān wa-mawāḍi'-i ǐšān dar țūl wa-'ard wa-tawābici-i ān) were also utilized, inter alia, for astrological purposes. See Uluğ Bey'in Astronomi Cetvelleri = Zîc-i Uluğ Bey, ed. Mustafa Kaçar and Atilla Bir, Ankara, Kültür ve Turizm Bakanlığı, 2012. Instead of other alternative terminology including "astronomer/astrologer," or "heavenly practitioner" as suggested by Robert Westman in his The Copernican Question: Prognostication, Skepticism, and Celestial Order (Berkeley, University of California Press, 2011), I prefer the transliterated term munağğim as it serves well to establish historical accuracy and allude to the fluid boundaries between "astronomical" and "astrological" activities in the premodern Islamicate context. For the zĭg literature in the Islamicate context, in addition to the studies cited in fn. 5 also see François C. De Blois, David A. King and Julio Samso, "Zīdj," $E I^{2}$.

Given that al-Ṭussìs Zīğ-i $\bar{I}$ lh $h \overline{a n} \grave{\imath}$ was one of the most popular and quoted sources in the late medieval and early modern Islamicate astronomical/astrological literature, it is a great pity that a critical edition has yet to be produced. My quotations are from a copy at the Biblioteca Medicea Laurenziana, Or. 24, f. 3a-3b.

10 For the importance of the calculation of ța $l_{i}{ }^{i} /$ horoscopus (ascendant) for astrological predictions see David King and Toufic Fahd, "al-Ṭālic," $E I^{2}$. 
were put into use through different genres by different agents in different historical contexts than assuming a definitive, timeless separation between these closely interrelated disciplines.

Along with his presentation of 'ilm al-nuğüm as a noble science for the benefit of the royal audience, Širwānìs emphasis on rulers as the primary beneficiary of celestial knowledge is also worth noting. This leads us to the question of the role of the royal court in the cultivation of the science of the stars as well as the patronage of the munağgrims. The appeal to the expertise of munağğims is indeed one of the prevailing themes of court life throughout the late medieval and early modern era in the entire Eurasian landmass. Despite the rich literature on the political uses of astrology and its cultural and intellectual significance in the Renaissance and early modern Eurasian courts, the patronage of munağğims and the cultivation of astrology in premodern Islamicate court culture have not been systematically explored. ${ }^{11}$ It is

11 The relevant literature in the European historiography is vast; the following works I find particularly useful: Monica Azzolini, The Duke and the Stars: Astrology and Politics in Renaissance Milan, Cambridge-London, Harvard University Press ("I Tatti studies in Italian Renaissance history”), 2013; Darin Hayton, Crown and the Cosmos: Astrology and the Politics of Maximilian I, Pittsburgh, University of Pittsburgh Press, 2015. Islamic studies still lack detailed case studies of the courtly patronage of astrology, yet the following studies are worth highlighting: for the early Abbasid case see Dimitri Gutas, Greek Thought, Arabic Culture: The Graeco-Arabic Translation Movement in Baghdad and Early 'Abbāsid Society (2nd-4th/8th-1oth Centuries), London-New York, Routledge, 1998; Antoine Borrut, "Court Astrologers and Historical Writing in Early Abbasid Baghdad: An Appraisal," in The Place to Go: Contexts of Learning in Baghdād, 750-100o C.E., eds Jens Scheiner and Damien Janos, Princeton, The Darwin Press ("Studies in late antiquity and early Islam," 26), 2014, p. 455-501. Charles Burnett has briefly remarked upon the role of al-Qabīsī, one of the noted munağğims of the third/tenth century, at the court of Sayf al-Dawla, the Hamdanid emir of Aleppo. See his "Al-Qabīṣi’s Introduction to Astrology: From Courtly Entertainment to University Textbook", in Studies in the History of Culture and Science: A Tribute to Gad Freudenthal, ed. Resianne Fontaine, Ruth Glasner, Reimund Leicht and Giuseppe Veltri, Leiden-Boston, Brill ("Studies in Jewish history and culture", 30), 2011, p. 43-69. Petra Schmidl's study on the Rasulid sultan al-Ašraf 'Umar is a welcome contribution to the patronage of the study of heavens at the court of a Muslim ruler, one deeply interested in learning the science personally. See her "Magic and Medicine in a 13th-century Treatise on the Science of the Stars: The Kitāb al-Tabșira fí 'ilm al-nujūm of the Rasulid Sultan alAshraf 'Umar," in Herbal Medicine in Yemen. Traditional Knowledge and Practice, and Their Value for Today's World, eds Ingrid Hehmeyer and Hannelore Schönig, Leiden-Boston, Brill ("Islamic history and civilization", 96), 2012, p. 43-68. In the Andalusian context, in addition to the works of Julio Samsó, see especially Miquel Forcada's prosopographical study on the astrologers at 'Abd al-Rahmmān II's court: "Investigating the Sources of Prosopography: The Case of the Astrologers of 'Abd al-Rahmman II," Journal of Medieval Prosopography, 23 
true that the major astrological texts of Abū Ma šar (d. ca 272/886), Māšāallāh (d. ca 200/815-816), al-Qabīṣī (d. 356/967), or Kūšyār b. Labbān (d. 420/1029) have been edited, annotated, and translated into English or Latin. Yet the majority of the current scholarly treatment of astrology in Islamic history is slanted more towards the textual and philological examination of "Arabic" astrological "textbooks" produced in the so-called "classical" period of Islamic history than the historical-cultural and contextual analysis of its deployment in specific courtly contexts. Hence the study of the astrologically significant materials other than textbooks produced and circulated in the post-classical Islamicate world in languages besides Arabic remains a major desideratum.

(2002), p. 73-10o. Sonja Brentjes has published important survey studies on the courtly patronage of the mathematical and ancient sciences in the Islamicate culture, though she has not particularly examined astrology and the munağğims. The Timurid Mîrzā Iskandar b. 'Umar-Šayh (d. 818/1415) has received remarkable attention especially from art historians, thanks to his surviving illustrated horoscope, but the astronomical/astrological activities at his court have yet to be thoroughly examined. For a brief discussion on Mīrzā Iskandar's interest in astral sciences see Evrim Binbaş, "Timurid Experimentation with Eschatological Absolutism: Mīrzā Iskandar, Shāh Ni'matullāh Walī, and Sayyid Sharīf Jurjānī in 815/1412," in Unity in Diversity: Mysticism, Messianism and the Construction of Religious Authority in Islam, ed. Orkhan Mir-Kasimov, Leiden-Boston, Brill ("Islamic history and civilization", 105), 2014, p. 277-306, esp. p. 290-293. Aydın Saylı's seminal work on observatories in the Islamic history sketches the general contours of the late-medieval and early-modern court culture, but as his primary concern was to demonstrate the scientific achievements of the observatories, his discussion on the courtly patronage of astrology remains limited. See his The Observatory in Islam and Its Place in the General History of the Observatory, Ankara, Türk Tarih Kurumu Basımevi ("Publications of the Turkish Historical Society, series 7", 38), 1960. Salim Aydüz's work in Turkish on the institution of the munağğimbāš̌ (office of the chief court astrologer) in the Ottoman context was an important contribution for providing a useful inventory of the court munağğims throughout the course of Ottoman history. However, the vast scope (sixteenth to twentieth century) of his study inevitably led to omissions, including several important munağğims active at the late fifteenth- and early sixteenth-century Ottoman court. His insistence on the term munaǧğimbāš̌ is also not always historically accurate, especially for the period prior to the mid-sixteenth century. Moreover, Aydüz unfortunately pays little attention to the contents of the munağğims' original writings. See Salim Aydüz, "Osmanlı Devleti'nde Müneccimbaşlık Müessesesi," Belleten, 70/257 (2006), p. 167-264; based upon his MA thesis, Osmanlı Devletinde Müneccimbaşılık ve Müneccimbaşılar, Istanbul University, 1993. The Mughal court has also attracted the attention of scholars, exemplified in the works of Eva Orthmann. See especially her "Sonne, Mond und Sterne: Kosmologie und Astrologie in der Inszenierung von Herrschaft unter Humayun," in Die Grenzen der Welt: Arabica et Iranica ad honorem Heinz Gaube, eds Lorenz Lorn, Eva Orthmann and Florian Schwarz, Wiesbaden, Reichert, 2008, p. 297-306. 
It is beyond the purview of this article to discuss in depth the reasons for the overall disinsterest of Islamicists in astrological matters and materials, but it should be noted that the general reluctance in current historiography, especially in works on the history of science in the Islamicate world, is informed by the implicit scholarly consensus that "astrological" practices are to be passed over in silence as part of a strategy to avoid reinforcing Orientalist perceptions of the so-called "decline" of the rational sciences in the post-classical Islamicate world. ${ }^{12}$

Although astrology and the munağğims in the courtly environment have not received due scholarly attention in especially the late medieval and early modern Islamicate context, recent decades have witnessed a flourishing and promising interest in the role of "occult philosophy" and its penetration of both courtly circles and trans-regional scholarly networks, especially during the ninth/fifteenth and the first half of the tenth/sixteenth centuries. ${ }^{13}$ This period is sometimes defined as a "Messianic Age" whose intellectual outlook "comprehends in its various iterations everything from metaphysics, cosmogony

12 Robert Morrison's work deserves special mention here for its substantial discussion on the role of astrology in a late-medieval Islamic scholar's overall intellectual quests. See Robert G. Morrison, Islam and Science: The Intellectual Career of Nīzām al-Dìn Nīsābūrī, London-New York, Routledge ("Culture and civilization in the Middle East"), 2007, esp. p. $63-77$.

13 One of the pioneering works here is Jean Aubin, "Le mécénat timouride à Chiraz," Studia Islamica, 8 (1957), p. 71-88. The rest has been generated mostly within the last two decades: Cornell H. Fleischer, "The Lawgiver as Messiah: The Making of the Imperial Image in the Reign of Süleyman," in Soliman le magnifique et son temps, ed. Gilles Veinsten, Paris, La Documentation Française ("Rencontres de l'École du Louvre"), 1992, p. 159-177; id., "Seer to the Sultan: Haydar-i Remmal and Sultan Süleyman," in Cultural Horizons: A Festschrift in Honor of Talat S. Halman, ed. Jayne L. Warner, New York, Syracuse University Press, 2001, I, p. 290-300; id., "Ancient Wisdom and New Sciences: Prophecies at the Ottoman Court in the Fifteenth and Early Sixteenth Centuries," in Falnama: The Book of Omens, eds Massumeh Farhad and Serpil Bağcı, London-Washington, Thames \& Hudson-Freer Gallery of Art, 2009, p. 231-245; Mohammad Masad, The Medieval Islamic Apocalyptic Tradition: Divination, Prophecy and the End of Time in the 13th Century Eastern Mediterranean, PhD dissertation, Washington University in St. Louis, 2008; Evrim Binbaş, Intellectual Networks in Timurid Iran: Sharaf al-Dīn 'Alì Yazdī and the Islamicate Republic of Letters, Cambridge, Cambridge University Press ("Cambridge studies in Islamic civilization"), 2016; Azfar Moin, The Millennial Sovereign: Sacred Kingship and Sainthood in Islam, New York, Columbia University Press ("South Asia across the disciplines"), 2012; Matthew Melvin-Koushki, The Quest for a Universal Science: The Occult Philosophy of Șāin al-Dīn Turka Ișfahānī (1369-1432) and Intellectual Millenarianism in Early Timurid Iran, $\mathrm{PhD}$ dissertation, Yale University, 2012. 
and physics to numerology, astrology and magic."14 Without a doubt Islamic history is replete with periods of millenarian activity and heightened apocalyptic expectations, but the geographical and temporal scope as well as the impact of the ninth/fifteenth-and tenth/sixteenth-century chapters of this history are quite unprecedented. ${ }^{15}$ The unprecedented nature of the select period derives mostly from the fact that this transitional era following the devolution of the Abbasid and Chingizid models of rule and preceding the consolidation of the territorial Muslim empires of the Ottomans, Safavids, and Mughals provided a suitable political and cultural environment for messianic movements to gain a stronger foothold. ${ }^{16}$ Moreover, the turn of the tenth century Hijra by 900/1494-1495 also roused among certain social segments expectations about the imminence of the end of the first Islamic millennium, and thus the end times.

As Cornell Fleischer and Sanjay Subrahmanyam - two scholars who have pioneered the study of the tenth/sixteenth-century florescence of messianic thought in the wider Islamic world—convincingly suggest, these messianic and millenarian themes circulated throughout a vast geography ranging from the Mediterranean to the Indian Ocean, and penetrated both learned and popular circles. ${ }^{17}$ This was a period in which "the future was as important as the past [...] and astrology as valuable as history."18 This millenarian discourse (or, as Azfar Moin has called it, "the science of the millennium") encouraged individuals to speculate with astrological and other divinatory methods to predict and even initiate the expected cosmic changes. ${ }^{19}$ Astrological theories and

14 Melvin-Koushki, The Quest, p. 5-6. See also Shahzad Bashir, Messianic Hopes and Mystical Visions: The Nūrbakhshīya Between Medieval and Modern Islam, Columbia, University of South Carolina Press ("Studies in comparative religion"), 2003.

15 For a useful historical survey of millennarian and apocalyptic activities see Imagining the End: Visions of Apocalypse from the Ancient Middle East to Modern America, ed. Abbas Amanat and Magnus Thorkell Bernhardsson, London-New York, I.B. Tauris, 2002.

16 For the importance of the ninth/fifteenth century in terms of political experimentation and ideological innovation see John E. Woods, The Aqquyunlu: Clan, Confederation, Empire, Salt Lake City University of Utah Press, 1999, p. 1-10; İhsan Fazlığlu, "Forcing the Boundaries in Religion, Politics and Philosophy-Science in the Fifteenth-Century" (paper presented at the conference Before the Revolutions: Religions, Sciences and Politics in the Fifteenth Century, Berlin, January 13-15, 2005).

17 Fleischer, "Ancient Wisdom"; Sanjay Subrahmanyam, "Turning the Stones Over: Sixteenth-Century Millenarianism from the Tagus to the Ganges," Indian Economic and Social History Review, 45/2 (2003), p. 129-161.

18 Azfar Moin, The Millennial Sovereign, p. 11.

19 Ibid., p. 9. 
techniques were indeed used as grounds for validating messianic claims and justifying apocalyptic speculations. ${ }^{20}$ Muhammad Nūrbahš (d. 869/1464), for instance, referred explicitly to Ptolemy and Nașîr al-Dīn al-Ṭūsī in his claim to be the messianic savior (Mahdī). ${ }^{21}$ The Ottoman sultan Süleymān (r. 926/1520974/1566) was feted, based upon astrological and/or lettrist principles, as the șāhib-qirān (prophesied world ruler, lit. 'Lord of Conjunction') and Mahdī of the end times. ${ }^{22}$ The ceremonies held at the Mughal court of Humāyūn (r. 937/1530-947/1540, 962/1555-963/1556) were organized based on astrological and cosmological principles. ${ }^{23}$ However, with few exceptions, most of these studies use as evidence rather non-technical texts such as popular narratives and hagiographies, chronicles and verse histories, or legal manuals, into which astrological concepts, and indeed a broader occult discourse, easily permeated. ${ }^{24}$ The actual writings of the munağğims themselves and the nature

$20 \quad$ For the early Islamic use of astronomy in messianic claims see David Cook, "Messianism and Astronomical Events during the First Four Centuries of Islam," Revue du monde musulman et de la Méditerranée, 91-94 (2001) [Mahdisme et Millenarisme en Islam, dir. Mercedes Garcia-Arenal], p. 29-51. This seems also true for the early-modern European religious realm. See the articles in Paola Zambelli (ed.), 'Astrologi hallucinati.' Stars and the End of the World in Luther's Time, Berlin-New York, de Gruyter, 1986; id., "Fine del mondo o inizio della propaganda?," in Scienze, credenze, occulte, livelli di cultura: Convegno Internazionale di Studi, Firenze, L.S. Olschki ("Atti di Convegni / Istituto nazionale di studi sul Rinascimento", 14), 1982, p. 291-368.

21 Shahzad Bashir, "The Risālat al-Hudā of Muhammad Nūrbaǩš (d. 869/1464): Critical Edition with Introduction," Rivista degli Studi Orientali, 75/1-4 (2001), p. 87-137.

22 In addition to the works of Fleischer cited above see Barbara Flemming, "Sāhịib-ḳrān und Mahdī: Türkische Endzeiterwartungen im ersten Jahrzehnt der Regierung Süleymāns," in Between the Danube and the Caucasus, ed. György Kara, Budapest, Akadémiai Kiadó ("Oriental sources on the history of the peoples of South-Eastern and Central Europe," 4), 1987, p. 43-62. For the historical assessment of the emergence of the term șăhib-qirān see Naindeep Singh Chann, "Lord of the Auspicious Conjunction: Origins of the Sahib-Qiran," Iran and the Caucasus, 13 (2009), p. 93-110.

23 Eva Orthmann, "Court Culture and Cosmology in the Mughal Empire: Humāyūn and the Foundations of the din-i ilähï," in Court Cultures in the Muslim World: Seventh to Nineteenth Centuries, ed. Albrecht Fuess and Jan-Peter Hartung, London-New York, Routledge ("SOAS-Routledge studies on the Middle East", 13), 2011, p. 202-220.

24 Ali Anooshahr also raises a similar criticism in his review of Azfar Moin's study. See his review article published in The Medieval History Journal, 18/1 (2015), p. 183-191. It is another contention of mine that despite the current promising status of the studies on the impact of messianic claims couched in occult-scientific discourse, one major pitfall in the field is the tendency to put everything in the same basket without paying the required attention to the important epistemological nuances between different (occult-)scientific practices. Especially when astrology is in question, the many different forms of its practice and 
of their complex relationships with their royal patrons still await thorough investigation to determine whether the astrological materials produced and circulated at the time were really informed by, and did further promote, such messianic and millenarian political ambitions.

The present study helps supply this significant lacuna by describing and analyzing the range of the patronage of munağğims at the court of Bāyezīd II (r. 886/1481-918/1512). Bāyezīd II, of course, was certainly not the only Muslim ruler, let alone Ottoman sultan, who showed a marked interest in the services of munağğims. Nevertheless, in light of the sheer number of munağğims employed, texts and instruments commissioned, and the contemporary testimonies as to the sultan's genuine celestial interests, I argue that the courtly cultivation of the science of the stars reached an unprecedented level under Bāyezīd II. To a certain extent, this study applies to the Ottoman context the question Jean Aubin asked almost five decades ago with specific reference to the Timurid realm: what do we know about the intellectual character and aspirations of a prince? ${ }^{25}$ I propose that Bāyezīd's documented interest in personally studying the science of the stars and patronizing a large number of astral experts during a period of political uncertainty, fraught constitutional issues, and a contested cultural environment was part and parcel of his efforts to establish the Ottoman court, and his own royal person, as the paramount political and intellectual center of its time.

\section{The Complex Image of Bāyezīd II}

The Ottoman historiography that traditionally ranks the reigns of the sultans based on military achievements, territorial gains, and political stability has largely downplayed the relatively long rule of Bāyezīd in contrast to the "heroic" reigns of his father Mehmed the Conqueror (r. 848/1444-850/1446, 855/1451-886/1481), and those of his immediate successors, his son Selìm I (r. 918/1512-926/1520) and grandson Süleymān. In fact, from the mere perspective of military history, Bāyezīd II did expand the Ottoman territory by conquering various important places such as Kilia, Akkerman, and several

consultation - some purely mathematical/astronomical and others entirely esotericshould always be taken into consideration.

25 In his influential article where he asks what modern historians know about the character of any Timurid prince, Aubin replies in a non-affirmative manner and says that not much is known about their personal intellectual aspirations. See Aubin, "Le mécénat timouride à Chiraz." 
Venetian enclaves on the coasts of Dalmatia, Albania and Mora. The navy he constructed is also credited with enabling Selīm's conquest of the Mamluk Sultanate. ${ }^{26}$ However, due to a number of misconstruals, neither current scholarship nor its more popular offshoots have much favored the period of his reign and the policies he implemented. ${ }^{27}$

His so-called "pious" personality is often held responsible in modern Ottoman historiography for isolating the Ottoman Empire from the cultural and intellectual achievements attained in contemporary Europe. In that respect Bāyezīd II is usually contrasted to his father Mehmed II, who is quite anachronistically labeled an "enlightened" ruler-partly because of his learned interests and curiosity towards Byzantine tradition as well as other contemporary monotheistic belief systems, and partly due to his commissioning of translations from Greek to Arabic along with portraits by Italian painters. ${ }^{28}$ Bāyezīd II, by contrast, is condemned for hampering the perpetuation of the cultural orientations and political ambitions prevalent at the court of his father. Leonardo da Vinci's plea to Bāyezīd II to construct a bridge over the Golden Horn fell on deaf ears, for example, and the sultan sold the paintings and disposed of Christian relics kept by his father in the palace. ${ }^{29}$ Bāyezīd II also allegedly turned down Christopher Columbus when the Genoese

26 On his endeavors to reorganize the Ottoman navy and create a stronger sea force with better technology, see Hans Joachim Kissling, "Betrachtungen über die Flottenpolitik Sultan Bâjezids II (1481-1512)," Saeculum, 20 (1969), p. 35-43; Palmira Johnson Brummett, Ottoman Seapower and Levantine Diplomacy in the Age of Discovery, Albany, State Unviersity of New York Press ("Suny series in the social and economic history of the Middle East"), 1994, p. 89-121.

27 See for instance Selahattin Tansel, Sultan II. Bāyezíd'in Siyasi Hayatı, Istanbul, M.E.B. Devlet Kitapları Müdürlüğü, 1966; Vernon J. Parry, "The Reigns of Bāyezīd II and Selim I, 1481-1520," in A History of the Ottoman Empire to 1730, ed. Michael Allan Cook, CambridgeNew York, Cambridge University Press, 1976, p. 54-78; Şerafettin Turan, "Bāyezīd II," Türkiye Diyanet Vakfi İslam Ansiklopedisi; Feridun Emecen, Imparatorluk Çağının Osmanlı Sultanları, Istanbul, İSAM Yayınları, 2011.

28 For a recent review of the studies that contrast the reign of Bāyezīd II to his father see Cihan Yüksel Muslu, "Ottoman-Mamluk Relations and the Complex Image of Bāyezīd II," in Conquête ottomane de l'Égypte (1517): Arrière-plan, impact, échos, dir. Benjamin Lellouch and Nicolas Michel, Leiden-Boston, Brill, 2013, p. 51-76.

29 Julian Raby, "A Sultan of Paradox: Mehmed the Conqueror as a Patron of the Arts," Oxford Art Journal, 5 (1982), p. 3-8; Semavi Eyice, "II. Bāyezīd Devrinde Davet Edilen Batılılar," Belgelerle Türk Tarihi Dergisi, 19 (1969), p. 23-30. The Archive of the Topkapı Palace Museum houses an undated copy of Leonardo's letter (TSMA E. 6184) showing that he also proposed to devise for the sultan a number of other things, such as a new kind of windmill and a sort of pump to empty out the water in the vessels. 
navigator approached him as a potential patron before embarking upon his costly expeditions. ${ }^{30}$ Moreover, Bāyezīd II has long been criticized for failing to take necessary measures against the emerging Safavid threat, with which his son Selim was left to deal during both his governorship in Trabzon and his sultanate in Istanbul. ${ }^{31}$ One could note further reasons for the scholarly disdain for the reign of Bāyezìd II, including his inability to achieve a decisive victory against the Mamluks, and his elimination of Mehmed II's favorite son Ğem Sultān (d. 900/1495) after a long struggle that soon gained an international character with the involvement of the Pope and several European powers. ${ }^{32}$ All these reasons have coalesced in contemporary scholarship with an image of Bāyezìd II as the weakest link in the so-called Ottoman golden age from the mid-ninth/fifteenth to the mid-tenth/sixteenth century.

Despite the conventional representation of Bāyezīd II's reign as a failure on a range of fronts, several cultural and literary historians were aware that Bāyezìd II was an avid patron of the arts and belles-lettres. ${ }^{33} \mathrm{He}$ is generally

30 As to the dialogue between the sultan and Columbus, there is no contemporary evidence that could prove Columbus really did approach the sultan; the earliest implied criticism directed against Bāyezìd for denying Columbus comes from the seventeenth century. The famous Ottoman traveller and writer Ewliyā Čelebī (d. after 1096/1685) fancifully narrates in the last volume of his Seyāhatnāme that, when Columbus and another Spaniard named Padre informed Bāyezīd of the New World they had recently discovered and advised him to launch an expedition toward this "virgin" land to take its riches, Bāyezīd allegedly declined, saying, "Mecca and Medina and this Old World are enough to conquer and there is no need to go overwhelming distances." See: Ewliyā Čelebī, Seyāḥatnāme, eds Robert Dankoff, Seyit Ali Kahraman and Yücel Dağll, Istanbul, Yapı Kredi Yayınları, 2007, X, p. 267.

The available scholarly conviction as to Bāyezĩd's idleness vis-à-vis the emerging Safavid power is based primarily on the Selimnāme literature, the earliest examples of which were produced as early as the later years of Selīm's reign. The purpose of these works is to valorize Selim and single him out as the only member of the Ottoman house that handled the Safavid problem seriously. However, archival documents from the reign of Bāyezīd clearly show that Bāyezīd was closely following the Safavid problem and taking active measures, although he did not initiate an open battle. See Feridun Emecen and İlhan Şahin, II. Bāyezìd dönemine ait 9o6/15or tarihli ahkam defteri, Istanbul, Türk Dünyası Araştırmaları Vakfı, 1994.

32 Halil İnalcık, "A Case Study in Renaissance Diplomacy: The Agreement between Innocent VIII and Bāyezīd II on Djem Sultan," Journal of Turkish Studies, 3 (1979), p. 209-223.

33 İsmail E. Erünsal, "Türk Edebiyatının Arşiv Kaynakları I: II. Bāyezīd Devrine Ait bir İnamat Defteri," IÜEF Tarih Enstitüsü Dergisi, 10-11 (1981), p. 303-348; Julian Raby and Zeren Tanınd, Turkish Bookbinding in the 15th Century: The Foundation of an Ottoman Court Style; Hilal Kazan, XVI. Asırda Sarayın Sanatı Himayesi, Istanbul, Ircica ("ISAR Vakfi yayınları", 30; "Yıldız Yayıncılık, Reklamcılık yayınları”, 17), 2010; Zeren Tanındı, "II. Bāyezīd’in Sanatlı 
considered the founding patron of Ottoman dynastic history writing, having eagerly commissioned the first dynastic histories of Ottoman rule. ${ }^{34}$ Modeled in the main on Timurid precedent, the voluminous histories of figures like Idrīs Bidlīsī (d. 926/1520), who wrote in Persian, and Kamāl Pāšāzāda (d. 940/1534), in refined Ottoman Turkish, helped not only to construct a prominent place for the Ottoman house in the universal unfolding of events but also to spotlight the rule and court of Bāyezīd II as supreme among previous and contemporary sovereigns, both politically and culturally. ${ }^{35}$ In addition to his active involvement as patron of the first dynastic histories of the Ottoman house, Bāyezīd II also lavishly supported a number of poets, calligraphers, and numerous artisans whom we can document thanks to the invaluable register of gifts and payments that record in great detail the names of all individuals receiving allowances from the sultan from 909/1503 to 918/1512. ${ }^{36}$ An equally remarkable

Kitapları," in Qașāyid-i Efșāḥi der meậh-i Sulțān Bāyezìd, Istanbul, Sakıp Sabancı Müzesi, 2012, p. 7-33.

Halil İnalcık, "The Rise of Ottoman Historiography," in Historians of the Middle East, ed. Bernard Lewis and Peter Malcolm Holt, London, Oxford University Press, 1962, p. 152-167; Victor Louis Ménage, "The Beginnings of Ottoman Historiography," in ibid., p. 168-179.

İnalcık, "The Rise of Ottoman Historiography"; Sara Nur Ylldız, "Ottoman Historical Writing in Persian, 1400-16oo," in Persian Historiography, ed. Charles Melville, LondonNew York, I.B. Tauris (“A history of Persian literature”, 10), 2012, p. 436-502; Vural Genç, Acem'den Rum'a: İdris-i Bidlisinin Hayatı, Tarihçiliǧive Heşt Behişt'in II. Bāyezīd Kısmı (14811512), PhD dissertation, Istanbul University, 2014; Christopher Markiewicz, The Crisis of Rule in Late Medieval Islam: A Study of Idrīs Bidlīsì (861-926/1457-1520) and Kingship at the Turn of the Sixteenth Century, PhD dissertation, University of Chicago, 2015. I would like to thank Vural Genç and Christopher Markiewicz for sharing their unpublished works with me.

36 Atatürk Kitaplığı Muallim Cevdet 0. 71. This voluminous register has been mined by several scholars for different purposes. In addition to the works of Erünsal and Kazan cited above see Rıfkı Melül Meriç, Türk Nakış Tarihi Araştırmaları, Ankara, 1953; id., "Bāyezīd Camii Mimarı, II. Bāyezīd Devri Mimarları ile Bazı Binalar, Bāyezīd Camii ile ilgili hususlar, san'atkarlar ve eserleri," Ankara Üniversitesi İlahiyat Fakültesi Türk ve İslam Sanatları Tarihi Enstitüsü Yıllık Araştırmalar Dergisi, 2 (1958), p. 4-76. While the records for the first two years were already made available by Ömer Lütfi Barkan and Mustafa Açıgöz, the full transliteration of the entire register has recently been completed by İlhan Gök. See Ömer Lütfi Barkan, “İstanbul Saraylarına ait Muhasebe Defterleri," Belgeler, 9/13 (1979), p. 1-380; Mustafa Açıkgöz, II. Bāyezìd Devri İnamat Defteri (Muharrem-Zilhicce 9ı/HaziranMayıs 1504-1505), MA thesis, Marmara University, 1996; İlhan Gök, Atatürk Kitaplığı M.C. O.71 Numaralı 909-933/1503-1527 Tarihli İnamat Defteri (Transkripsiyon-Değerlendirme), PhD dissertation, Marmara University, 2014. 
but lesser known aspect of Bāyezīd II's patronage is his benefaction towards experts in 'ilmal-nuğūm.

\section{Bāyezīd II as Patron of 'ilm al-nuğūm}

Before detailing the unprecedented scope of his support for experts in the science of the stars, it is necessary to briefly sketch the story of munağğims at the Ottoman courts prior to the reign of Bāyezìd II. Although the earliest hard evidence of a munağğim in the service of an Ottoman ruler only dates to the first half of the ninth/fifteenth century, it does not strain credibility to assume that there were munağğims around the ruling party from its early days, given the frequent use of the expertise of the munağgims at the courts of other dynasties before the Ottomans, including, for instance, the Seljuqs of Rum and several other Anatolian principalities. ${ }^{37}$ The tasks munağğims were expected to fulfil are not clear, though it appears they provided, as experts in different applications of the science of the stars, a number of services, ranging from measurement of time for daily prayers and calculation of days on the basis of various calendrical systems to astrological counseling and determination of auspicious moments to initiate an imperial enterprise. The most important textual tool of a practicing munağğim was the taqwim (annual almanac-prognostication), which was composed and presented to the court around the time of the turning of the new year (tahwill-i sāl-i 'a alam) with the spring equinox in March (i.e. Nawrūz). ${ }^{38}$ The modern connotations of the word taqwimmeaning calendar in modern Turkish and Persian - are usually misleading as they give the false impression that these annual ephemeral pieces were composed solely for calendrical purposes. ${ }^{39}$ Calendrical information did indeed occupy a greater amount of space in each taqwim, but these annual ephemeral texts were geared towards tabulating the positions of the sun, moon, and planets (taqwim al-kawākib) during the course of the year, and then propounding,

37 Osman Turan, Türkiye Selçukluları Hakkında Resmi Vesikalar: Metin, Tercüme ve Araştırmalar, Ankara, Türk Tarih Kurumu Basımevı ("Turk Tarih Kurumu Yayınları VII. Seri", 32), 1968, p. 174. There is an extant taqwìm (MS Süleymaniye, Nuruosmaniye, 2782) written in the year 773/1371-1372 by a certain Zayn al-Munağğim b. Sulaymān al-Qūnawī, who must have been close to the court of Eretna, as the internal evidence suggests.

38 The history of the taqwim in the pre-modern Islamicate world is yet to be written. For a useful general overview see Michael Hofelich and Daniel Martin Varisco, "Takwīm," $E I^{2}$.

39 See for instance Stephen P. Blake, Time in Early Modern Islam: Calendar, Ceremony, and Chronology in the Safavid, Mughal, and Ottoman Empires, New York, Cambridge University Press, 2013; Salim Aydüz, "Osmanlı Devleti'nde Müneccimbaşılık Müessesesi.” 
based upon the calculated planetary positions, astrological predictions as to the fortunes of the upcoming year.

While the oldest extant example of the taqwim genre in the Ottoman realm dates to the later years of the reign of Mehmed I (r. 816/1413-824/1421), the earliest taqwim featuring the autograph of a munağgyim is from the reign of Murād II (r. 824/1421-848/1444, 850/1446-855/1451). In 843/1439, a certain Ibrāhīm b. šayh al-munağğimìn wa-l-rammāl, better known as Ibn al-Ǧamāl, presented the sultan with a taqwim in Persian in which he conveyed his astrological predictions as to the fortunes and mishaps of the upcoming year. ${ }^{40}$ There are also few available taqwims from the time of Mehmed II, yet none of them bears an autograph that could enable us to identify the name of a munağğim at his court. There are contemporary literary sources that refer to a group of munağğims around Meḥmed II whom he would consult to designate the auspicious time for important military expeditions or the construction of imperial buildings. One of these sources is Cardinal Isidoro (d. 1463), the Greek metropolitan of Kiev who, as an eyewitness to the siege of Constantinople, says in one of his letters that Mehmed asked his "Persian" munağğims to designate the auspicious time to start the siege.$^{41} \mathrm{~A}$ similar story may also be found in the Ottoman sources. Tursun Bey (d. after 896/1491), for example, recounts that the munağğims calculated an auspicious moment for the construction of the fortress in the Bosphorus before the siege of Constantinople, but he does not specify their ethno-geographic affiliations. ${ }^{42}$ Ǧem Sultạn also appears to have developed an interest in the science of the stars toward the end of his life. In an astrological work (Miftāh al-nuğüm) composed in Turkish and presented to the prince in the year 874/1479, its author Yahyā b. Husayn Yahyā says that he used to annually deliver a taqwìm to Ğem Sulțān who eventually became curious about the science of the stars and requested a book simple enough to teach him the basics of it. ${ }^{43}$

Despite the sources' allusions to a number of (Persian) munağğims at the court of Mehmed II, the archival records from the period tell a different story.

$40 \quad$ MS BN Pers 367 , f. 2a. The earliest extant taqwim produced for an Ottoman ruler was crafted in the year 824/1421 for Mehmed I. For the transliteration of its chronology section, see Nihal Atsız, Osmanlı Tarihine Ait Takvimler I: 824, 835 ve 843 tarihli takvimler, Istanbul, Küçükaydın Matbaası, 1961, p. 8-57.

41 Quoted in Agostino Pertusi, La caduta di Costantinopoli, Milano, Fondazione Lorenzo Valla ("Scrittori greci e latini"), 1976, I, p. 75 .

42 Tursun Bey, Tarih-i Ebü'l-Feth, ed. Mertol Tulum, Istanbul, Istanbul, Baha Matbaası, 1977, p. 44.

43 MS Istanbul, Topkapı Palace Museum Library, Revan, 1704, f. 4 b. 
There is not much available in terms of archival documents from the time of Mehmed II, though a relatively detailed payroll book from the year 883/1478 lists the names of palace personnel, including the munağğims. Contrary to what is depicted by literary sources, there is only one munağğim, Mawlānā Kūčak, who was receiving 10 aspers daily, which is equal to the pay range of a messenger or a gatekeeper but significantly lower than a falconer or storyteller. ${ }^{44}$ Mawlānā Kūčak is listed in the register under the loosely defined $m u$ tafarriqa corps, which also hints that there was not a designated unit for the munağğims within the nascent bureaucracy of the time. ${ }^{45}$

By the time of Bāyezìd II, however, the number, the status, and the salaries of the munağğims had significantly changed. Another payroll book—which must have been drafted sometime between 906/1500 and 917/1511, according to internal evidence-lists six munağğims that receive in sum 6 o68 aspers monthly, making an average daily salary of a court munağğim 33,7 aspers. ${ }^{46}$ Unfortunately the list does not specify the names of these munağğims, yet catalogs them as an individual unit (ğamā'at-i munağğimin) under the monthly salaried palace personnel (mušăhara-huūrān) rubric. ${ }^{47}$ The famous register of allowances that covers the last decade of the reign of Bāyezīd II also corroborates the information given in the payroll book. According to this voluminous register, at least twenty different names are recorded as munağğims, muwaqqits (time-keepers) or other individuals presenting the court with a taqwim. Within these numerous names, at least five of them are listed under mušāhara-hürān rubric. Based upon these two registers, it is possible to deduce that there were five or six munağğims permanently employed at the court of Bāyezīd II.

In terms of the number of munağğims who found stable employment at the Ottoman court, Bāyezīd's reign supersedes not only those of his predecessors but also those of his successors. For example, a register from the year 920/1514 during the reign of Selimm documents that the unit of court astrologers (ğamā'at-i munağğiminn) was composed of four munağğims, but unfortunately

44 Ahmed Refik, "Fatih Devrine ait Vesikalar," Tarih-i Osmani Encümeni Mecmuası, 8-11/49-62 (1335/1919), p. 1-58.

45 For the mutafarriqa corps see İsmail H. Uzunçarşılı, Osmanlı Devletinin Saray Teşkilatı, Ankara, Atatürk Kültür, Dil ve Tarih Yüksek Kurumu, 1984, 428-431; Tayyib Gökbilgin, "Müteferrika," Milli Eǧitim Bakanlığı İslam Ansiklopedisi.

46 Tsma D. 9587, also quoted in Ömer Lütfi Barkan, "H. 933-934 Tarihli Bütçe Cedveli ve Ekleri,” Íktisat Fakültesi Mecmuası, 15/1-4 (1953-1954), p. 309.

47 For the mušāhara-huürān status see Linda Darling, "Ottoman Salary Registers as a Source for Economic and Social History," Turkish Studies Association Bulletin, 14/1 (1990), p. 13-33. 
their names and salaries are not specified. ${ }^{48}$ Another pay register from the first decade of the reign of Süleymān lists three munağğims under the rubric of the monthly salaried palace personnel, each receiving 15,14 , and 10 aspers daily respectively. ${ }^{49}$ It is also worth noting that all three of these munağğims, Sayyid Ibrāhīm b. Sayyid Munağğim, ${ }^{50}$ Isḥāq Munaǧğim, and Sinān Munağğim, had started their careers at the court of Bāyezìd II. Other archival documents from the later periods of the reign of Süleymān also confirm that the number of court munağğims was never greater than three, and as evinced by both archival sources and contemporary literary testimony of figures like 'Āšiq Čelebī (d. 979/1572), the number even dropped to two through the end of Süleymān's reign. ${ }^{11}$

TABLE 1 The list of court munağğims and other individuals who present taqwìms to Sulțān Bāyezìd from 909/1503 to 918/1512.

\begin{tabular}{|c|c|c|c|c|c|}
\hline Name & Status & $\begin{array}{l}\text { Occasions } \\
\text { for receiving } \\
\text { allowances }\end{array}$ & $\begin{array}{l}\text { Allowances } \\
\text { received for } \\
\text { presenting } \\
\text { taqwim }\end{array}$ & $\begin{array}{l}\text { Special } \\
\text { occasions }\end{array}$ & Active years \\
\hline $\begin{array}{l}\text { Mawlānā } \\
\text { Sayyid } \\
\text { Munaǧǧim }\end{array}$ & $\begin{array}{l}\text { mušāhara- } \\
\text { hūrāan }\end{array}$ & $\geq 33$ & $\geq 8$ & $\begin{array}{l}1 \text { for the loss } \\
\text { of his son }\end{array}$ & $\begin{array}{l}909 / 15^{03-} \\
918 / 1512\end{array}$ \\
\hline $\begin{array}{l}\text { Mawlānā } \\
\text { Mīrim } \\
\text { Čelebī }\end{array}$ & $\begin{array}{l}\text { mušāhara- } \\
\text { hūrāān }\end{array}$ & $\geq 18$ & $\mathrm{~N} / \mathrm{A}$ & $\begin{array}{l}1 \text { for his } \\
\text { wedding } \\
\text { expenses, } \\
2 \text { times for } \\
\text { his wife's } \\
\text { consumption }\end{array}$ & $\begin{array}{l}909 / 15^{03}- \\
918 / 1512\end{array}$ \\
\hline
\end{tabular}

48 TSMA D. 5475, also quoted in Ömer Lütfi Barkan, "H. 933-934 Tarihli Bütçe Cedveli ve Ekleri," p. 313 .

49 TSma D. 7843, also quoted in Ömer Lütfi Barkan, "H. 933-934 Tarihli Bütçe Cedveli ve Ekleri," p. 323 .

5o While it is clearly written in the document as Ibrāhīm, his son, who started his tenure as one of the court munağğims under Bāyezīd II, is recorded in the voluminous gift register as Ismāîl. This raises the question as to whether he had two sons employed at Bāyezīd's court.

$5^{1} \quad$ Aydüz, "Osmanlı Devleti'nde Müneccimbaşlık Müessesesi”; Aşı Çelebi, Meşa’irü’şŞuara, ed. Filiz Kılıç, Istanbul, Suna ve İnan Kıraç Vakfi, 2010, III, p. 1398. 


$\begin{array}{lll}\text { Name Status } & \begin{array}{l}\text { Occasions } \\ \text { for receiving } \\ \text { allowances }\end{array} & \text { Allowances Special } \\ & \text { presenting } \\ & \text { taqwim }\end{array}$

\begin{tabular}{|c|c|c|c|c|c|}
\hline $\begin{array}{l}\text { Sinān b. } \\
\text { Munaǧğgima }^{a}\end{array}$ & $\begin{array}{l}\text { mušāhara- } \\
\text { hūrānn }\end{array}$ & $\geq 12$ & $\geq 5$ & $\mathrm{~N} / \mathrm{A}$ & $\begin{array}{l}909 / 15^{03}- \\
918 / 15^{12}\end{array}$ \\
\hline $\begin{array}{l}\text { Yūsuf b. } \\
\text { 'Umar } \\
\text { al-Sā'at̄̄ }\end{array}$ & $\begin{array}{l}\text { mušāhara- } \\
\text { hūrāan }\end{array}$ & $\geq 8$ & $\geq 3$ & $\begin{array}{l}1 \text { for Hağğ } \\
\text { expenses }\end{array}$ & $\begin{array}{l}911 / 15^{05} \\
918 / 15^{-}\end{array}$ \\
\hline $\begin{array}{l}\text { Ardašīir b. } \\
\text { Malik Ḥasan }\end{array}$ & $\begin{array}{l}\text { mušāhara- } \\
\text { hūrānn }\end{array}$ & $\geq 5$ & $\geq 5$ & $\mathrm{~N} / \mathrm{A}$ & $\begin{array}{l}911 / 15^{05} \\
918 / 15^{12}\end{array}$ \\
\hline $\begin{array}{l}\text { Salmān-i } \\
\text { 'Aǧam } \\
\text { munaǧǧim }\end{array}$ & unspecified & $\geq 9$ & $\geq 8$ & $\mathrm{~N} / \mathrm{A}$ & $\begin{array}{l}909 / 15^{03} \\
916 / 15^{10}\end{array}$ \\
\hline $\begin{array}{l}\text { Sayyid } \\
\text { Ismācīl b. } \\
\text { Sayyid } \\
\text { Munaǧğim }\end{array}$ & $\begin{array}{l}\text { son of } \\
\text { Sayyid } \\
\text { Munaǧğim }\end{array}$ & $\geq 8$ & $\geq 5$ & $\mathrm{~N} / \mathrm{A}$ & $\begin{array}{l}909 / 15^{03-} \\
918 / 15^{12}\end{array}$ \\
\hline $\begin{array}{l}\text { Isḥāq } \\
\text { munaǧǧim }\end{array}$ & unspecified & $\geq 8$ & $\geq 5$ & $\mathrm{~N} / \mathrm{A}$ & $\begin{array}{l}911 / 15^{05}- \\
918 / 15^{12}\end{array}$ \\
\hline 'Alī & $\begin{array}{l}\text { student of } \\
\text { Mīrim } \\
\text { Čelebī }\end{array}$ & $\geq 3$ & $\geq 3$ & $\mathrm{~N} / \mathrm{A}$ & $\begin{array}{l}912 / 1506- \\
916 / 1510\end{array}$ \\
\hline $\begin{array}{l}\text { Murād } \\
\text { muwaqqit }\end{array}$ & $\begin{array}{l}\text { time-keeper } \\
\text { at Edirne } \\
\text { Bāyezīd } \\
\text { Mosque } \\
\text { Complex }\end{array}$ & $\geq 2$ & $\geq 2$ & $\mathrm{~N} / \mathrm{A}$ & $\begin{array}{l}911 / 15^{05^{-}} \\
912 / 15^{06}\end{array}$ \\
\hline $\begin{array}{l}\text { Muhammad } \\
\text { b. Huiḍr }\end{array}$ & $\begin{array}{l}\text { sword- } \\
\text { bearer }\end{array}$ & $\geq 2$ & $\geq 2$ & $\mathrm{~N} / \mathrm{A}$ & $\begin{array}{l}911 / 15^{05} \\
912 / 15^{\circ}\end{array}$ \\
\hline Mīrzā Beg & $\begin{array}{l}\text { chief food } \\
\text { taster of } \\
\text { Šāhzāda } \\
\text { Aḥmad }\end{array}$ & $\geq 2$ & $\geq 2$ & $\mathrm{~N} / \mathrm{A}$ & $\begin{array}{l}914 / 1508- \\
916 / 1510\end{array}$ \\
\hline $\begin{array}{l}\text { Mawlānā } \\
\text { Sinān aka } \\
\text { Qāọī-yi } \\
\text { Baġdad }\end{array}$ & $\begin{array}{l}\text { mudarris at } \\
\text { Bursa } \\
\text { Sultaniya } \\
\text { madrasa }\end{array}$ & $\geq 1$ & $\geq 1$ & $\mathrm{~N} / \mathrm{A}$ & $\begin{array}{l}913 / 15^{07-} \\
914 / 1508\end{array}$ \\
\hline
\end{tabular}


TABLE 1 The list of court munağğims and other individuals (cont.)

\begin{tabular}{llll}
\hline Name Status & Occasions & Allowances Special & Active years \\
& for receiving & received for occasions & \\
& allowances & presenting \\
& & taqwim
\end{tabular}

\begin{tabular}{|c|c|c|c|c|c|}
\hline $\begin{array}{l}\text { 'Abd } \\
\text { al-Raḥmān }\end{array}$ & $\begin{array}{l}\text { munaǧǧim } \\
\text { of Šāhzāda } \\
\text { Aḥmad }\end{array}$ & $\geq 1$ & $\geq 1$ & $\mathrm{~N} / \mathrm{A}$ & $\begin{array}{l}915 / 1509- \\
916 / 1510\end{array}$ \\
\hline $\begin{array}{l}\text { Muhạammad } \\
\text { b. Qāḍ̄ī-yi } \\
\text { Uskūb }\end{array}$ & unspecified & $\geq 1$ & $\geq 1$ & $\mathrm{~N} / \mathrm{A}$ & $918 / 1512$ \\
\hline $\begin{array}{l}\text { Muhammad } \\
\text { b. Qāḍ̂̄-yi } \\
\text { Galībulī }\end{array}$ & unspecified & $\geq 1$ & $\geq 1$ & $\mathrm{~N} / \mathrm{A}$ & $918 / 1512$ \\
\hline Rağab & $\begin{array}{l}\text { student of } \\
\text { Sayyid } \\
\text { Munaǧğim }\end{array}$ & $\geq 1$ & $\geq 1$ & $\mathrm{~N} / \mathrm{A}$ & $918 / 1512$ \\
\hline $\begin{array}{l}\text { Mawlānā } \\
\text { Šams al-Dīn }\end{array}$ & unspecified & $\geq 1$ & $\geq 1$ & $\mathrm{~N} / \mathrm{A}$ & $\begin{array}{l}909 / 1503- \\
910 / 1504\end{array}$ \\
\hline
\end{tabular}

a While it is true that in the Ottoman textual culture the names Sinān and Yūsuf were often used interchangeably for individuals named as Sinān al-Dīn Yūsuf, it is more likely that these Sinān and Yūsuf b. 'Umar al-Sā'ātī are two different individuals, maybe even brothers as the sons of a certain 'Umar who is referred to in the register sometimes as muwaqqit, sometimes as mu'ad din, and sometimes as munağǧim. For example, in the relevant entries from the month of dū l-hiğğa in the year 916/March 1511, Sinān's name is recorded as the one given 500 aspers on the $25^{\text {th }}$ of that month for the taqwīm he presented whereas Yūsuf apparently received his customary 500 aspers on the 29 th.

Although we have at our disposal substantial sources to statistically sketch the astrological patronage of Bāyezīd II in the last decade of his reign, we are not that fortunate for the first two decades of his rule. Nevertheless, we can glean information about the munağğims around the court during his early years from the taqwims and related treatises presented to the sultan. These sources also help us flesh out these rather dry statistical facts and provide insights into the nature of the personal relationships established between the sultan and their munağğims. 
One of the most important munağğims during the early phases of his reign was Ḥusām b. Šams al-Dīn al-Lāhiǧānī al-Gīlānī, better known as Hițābī Munağğim al-Ḥusaynī. ${ }^{52}$ Hitạaī has yet to be the subject of an in-depth study and the references to his life in the available bio-bibliographical sources along with few other works are rather discordant. Some of those studies assert, as his name suggests, that Hुițābī was the son of Šams al-Dīn al-Lāhīğī (d. 912/1506?), the renowned disciple of Muhammad Nürbahš and the famous commentator on Šabistarı̄'s (d. 740/1340) popular mystical treatise Gulšan-i rāz..$^{53}$ The appeal to astronomical-astrological principles within Nūrbahšš circles, exemplified in the work of Muhammad Nūrbahš himself, does indeed suggest the possibility that Huitāaī could have been Šams al-Dīn al-Lāhīğǐ’s son. But we simply do not have decisive evidence to this effect, neither in Šams al-Dīn al-Lāhīğì's own writings, including his collection of poems, nor in the studies that briefly mention his life. ${ }^{54}$ The major bio-bibliographical source on the history of Ottoman astronomy and astrology lists a mid-ninth/fifteenth century copy of a commentary by al-Ṭūsī on pseudo-Ptolemy's Kitāb al-Ṭamara (aka Centiloquium), a seminal astrological work, as copied by Šams al-Dīn al-Lāhīğī. ${ }^{55}$ Nonetheless, this promising piece of evidence does not turn out to be true, as the colophon of the book clearly reads that the copy was drafted in the year $854 / 145^{\circ}$ by a certain Ismā̄îl b. Yūsuf Lāhīḡī. ${ }^{56}$

$5^{2}$ In the copies of his works that I have been able to examine, he writes his name without a šadda, although he puts šadda for other words where necessary. Hence, his pseudonym should be al-Hițābī, not al-Hatțābī as suggested in Osmanlı Astronomi Literatürü Tarihi/ History of Astronomy Literature during the Ottoman Empire, ed. Ekmeleddin İhsanoğlu, Istanbul, Ircica ("İlim tarihi kaynakları ve araştırmaları serisi", 7), 1997, I, p. 63-64. There is yet further confusion among other studies such as that of Babinger who thinks the author's name is al-Hițāyī. This last proposition cannot be true, as al-Hițābī explicitly says in the chronology section of his taqwìm that the calculation of the munağğimān-i Hițāy as to the age of the universe is different from the calculation of the munağğiman-i $m \bar{a}$, by which he is presumably referring to the astrologers from Irān-zaminn.

53 Ibid.

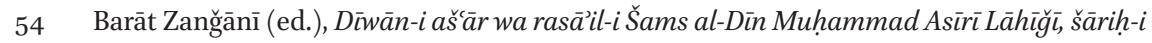
Gulšan-i rāz, Tehran, Mu’assasah-i Muțala’at-i Islami-i Dānišgāh-i Mak Gīl, 1357/1978; Bashir, Messianic Hopes and Mystical Visions.

55 Osmanlı Astroloji Literatürü Tarihi ve Osmanlı Astronomi Literatürü Tarihi/History of Ottoman Astrology Literature and Supplement to the History of Ottoman Astronomy Literature, ed. Ekmeleddin İhsanoğlu, Istanbul, Ircica, 2011, I, p. 13-14.

56 Ms Istanbul, Süleymaniye, Reisülküttab, 572, f. 222a. Tâǎköprüzāde, the major source for the lives of ninth/fifteenth and tenth/sixteenth century Ottoman scholars, mentions a certain preacher named Mawlānā Ḥusām from Gīlān, who is known as Dallākzāda and who was an expert in Qur’ān recitation. Țāšköprüzāde, al-Šaqā̉iq al-nu'māniyya, p. 205. 
In a recent study on an astronomical treatise composed by Huițābī in Istanbul in the year 887/1483 and presented to Sulțān Bāyezīd, it is argued without any convincing proof that Hițābī is the same person as Sayyid Munağğim, a relatively noted figure from the early Timurid context. ${ }^{57}$ Sayyid Munağğim is known as the author of astronomical and astrological works, including Risāla-i Šakl-i muġnì wa-zillı̄ and Latäif al-kalām fíahkām al-a'wām. ${ }^{58}$ As the contents of these two works indicate, Sayyid Munağğim flourished in the Timurid realm in the first decades of the ninth/fifteenth century. In the latter work, which eventually became a popular textbook for judicial astrology, he explicitly mentions his personal observation of the solar eclipse that occurred in the year 803/140o before the Battle of Ankara (804/1402) between the Ottomans and Timurids. ${ }^{59} \mathrm{He}$ also clearly writes his real name in these works as "Muhammad al-Husayn, al-mad'ü bi-Sayyid Munağğim." On the contrary, in the copies written by Hițābī, all of which date to the late ninth/fifteenth century, he writes his name either as Ḥusām b. Šams al-Dīn al-Hูațīb al-muštahir bi-Hițābī alGīlānī al-Lāhīǧānī or Huițābī Munağğim al-Ḥusaynī. He never identifies himself as Sayyid Munağğim. Given that Sayyid Munağğim from the Timurid realm was active at the turn of the ninth/fifteenth century and had a name documentedly different from that of Huițābī Munağğim al-Ḥusaynī, who served

Given that Taašköprüzāde does not ever mention any activity of his as to the science of the stars, it is highly unlikely that Dallākzāda and Hițābī were the same individual. Yet, the major bio-bibliographical sources on the history of Ottoman astronomy (i.e. History of Astronomy Literature during the Ottoman Empire) and astrology literature (i.e. History of Ottoman Astrology Literature and Supplement to the History of Ottoman Astronomy Literature) combine these two strands of information and falsely introduce a person named Dallākzāda l-Hูițābī l-Lāhiǧānī l-munağğim al-Gīlānī.

57 Mortaza Somi and Mohammad Bagheri, "Risāla-i tašrịh al-ālāt fĩ ša’n al-imtihāāāt az Sayyid Munağğim Ḥusaynī”, Mìrāt-i Tlmīi Islam wa-Iran, 2/1 (1392/2013), p. 181-205. I would like to thank Prof. İhsan Fazlığlu for bringing this article to my attention.

$5^{8}$ Sayyid Munağğim, whose name was Muhammad al-Ḥusayn, presented this work on 25 ramaḍān 837/3o April 1434 to Ulug Beg. See Ms Istanbul, Süleymaniye, Yazma Bağışlar, 1362. I am grateful to Abdurrahman Atçıl for sharing the digital copy of this manuscript with me. As for the Lațāîf al-kalām fí ahkām al-a'wām, I have examined a handful of copies, the earliest of which date back to the late sixteenth century. In the text itself, Sayyid Munağğim refers to the year $824 / 1421$ as the date he chose to designate the ascendant for the year. In all these copies his name is written as "Muhammad al-Husayn al-mad'uww bi-Sayyid (al-)Munağğim."

59 MS Istanbul, Boğaziçi University Kandilli Observatory Library, 310, f. 30b. Also see S. Mohammad Mozaffari, "The Effect of Astrological Opinions on Society: A Preliminary View," Trames, 16/4 (2012), p. 359-368. 
Bāyezìd II as late as ca 9oo/mid-149os, it seems highly unlikely that the two could be the same individual.

Who, then, was Hițābī l-Munağǧim al-Husaynī? He does not give us many clues to go on when writing about his family, teachers, and peers. He only refers in his treatise on a newly developed astronomical instrument (Risālat Tašrịh al-ālāt) to a certain Sayyid Rukn al-Dīn Āmulī (d. after 86o/1456) as his teacher, whom we know composed a treatise on the astrolabe (Risāla-i Panğāh $b \bar{a} b)$ and the Zì̆ğ-i ğadìd-i Sa $\bar{\imath} d \bar{l}_{.}{ }^{60}$ Although the zì̆ğ of Rukn al-Dīn Āmulì did not obtain much popularity among the munağğims in the Ottoman lands during the period in question, Hițābī praises it as one of the three most preferred

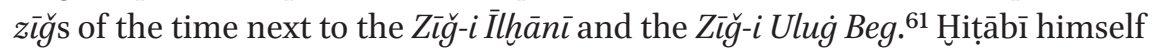
prefers to base his calculations on it when drafting annual astrological predictions in taqwim form. For example, in preparing the annual astrological predictions he presented to Bāyezīd II in the year 894/1489, Hițābī calculated the planetary positions and the astrological houses on the basis of the data given in his teacher's zĭğ. ${ }^{62}$

It is not certain when exactly Hitāāì came to the Ottoman realm. Certain notes from his writings suggest that he first tried to enter the service of Bāyezìd II while the latter was still governor in Amasya before he approached Sulțān Mehmed II by the later 870 s/1470s. One of his earliest works is a treatise on philosophy ('ilm al-ḥikma) called Ğämi' al-qismayn that he composed hastily in the year 884/1479-1480 in Tokat (in northeastern Anatolia, close to Amasya) and dedicated to prince Bāyezīd. ${ }^{63}$ As the title of the work suggests, Hițābī

6o Aydın Sayll, The Observatory in Islam, p. 212-216. In his treatise on astrolabes (Risāla-i panğāh $b \bar{a} b$ ), Rukn al-Dīn clearly says that the "fruit" (tamara) and ultimate reward of studying natural-philosophical ('ulūm-i hikmī) and mathematical sciences ('ulüm-i riya $\bar{a} \bar{\imath} \bar{\imath}$, including hay'a, handasa, and hisāb, is to be able to make astrological judgments ('ilm-i ahkām) and accurately measure the time. For Rukn al-Dīn, this relies upon the ability to observe the celestial objects, calculate the mean motions of planets (istihrāăg $i$ taqwìm-i kawākib), and designate the ascendants of the hour (țawālici $\left.i \bar{a}^{\prime} a t\right)$. See Rukn al-Dīn Āmulī, Risāla-i panǧāh bāb, Ms Istanbul, Süleymaniye, Ayasofya, 2667, f. 2a-2b.

61 Somi and Bagheri, "Risāla-i tašrīh al-ālāt," p. 183: wa-l-ān zīgăài ki dar aktar-i mamālik

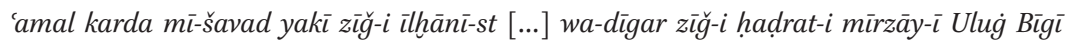

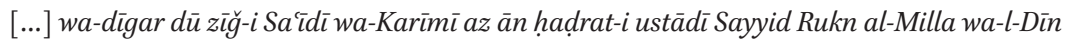
$\bar{A}$ mulī.

62 Ms Istanbul, Topkapı Palace Museum Library, Bağdat, 310.

63 Al-Hुițābī, Ğāmic al-qismayn, Ms Istanbul, Süleymaniye, Ayasofya, 2414M, ff. 19b-20a: muharrir-i in suțūr wa-muqarrir-i ìn mazbūr [...] Husām b. Šams al-Dīn al-Hațīb almuštahir bi-Huițābīal-Gīlānī [...] 'ağălat al-waqt-rā dar tārīhn-i sana-i 884 hiğriyya dar baldat 
reviews therein the two broad philosophical disciplines: mathematical sciences (hikmat-i riy $\bar{a} d \bar{l}$ ) and natural sciences (hikmat-i țabi $\vec{\imath})$. More precisely, he first elaborates on 'ilm-i nuğūm and, like Šukr Allāh Širwānī, delves into a strictly astrological discussion, laying out the qualities and indications of the twelve astrological houses. For him, 'ilm-i nuğüm, which is more exalted than medicine ( $i l m-i t i b b$ ), is a useful and divine knowledge that helps human beings understand the impact of the motions of the celestial objects on the sublunary world, guard against harm and destruction—as ordered in the Qurān-, and learn about the divine decree with respect to their personal lives. ${ }^{64} \mathrm{He}$ then proceeds to medicine and details diseases as well as the required medication for remedying each.

Hițābi most likely traveled to Istanbul by the end of the year 884/1479. In December of that year, he completed and dedicated to Mehmed II his long commentary on Nașīr al-Dīn al-Ṭūsìs popular almanac treatise Risāla dar Ma'rifat-i taqwìm, better known as Risāla-i Si fașl. Although Hițābī says that his main objective in writing this commentary is to make the concepts and the terminology used in al-Tūsìs text more comprehensible to beginners in this science, he later reveals his real desire is to attract the benevolence of Sultān Mehmed II. ${ }^{65}$ In fact, al-Ṭusis's treatise- originally a short introduction on the nature of the planets, the characteristics of the signs of the zodiac and the influences of different planetary positions - was already one of the most popular texts of the genre among the would-be munağğims in the Ottoman realm and Turkish translations of the work started to appear as early as the late eighth/ fourteenth century. ${ }^{66}$ Moreover, Hitāaī composed his work in Persian, which was not the first preference among students in the Ottoman lands. In this regard Hițābīs claim to have composed a text that would be helpful for novices does not sound quite realistic. That the work is preserved in a single copy and

al-mwwaḥhidīn Ṭūqāt [...] bi-ḥasab-i wasīla-i idrāk-i sa'ādat-i taqabbul-i turāb-i sudda-i rafĩa-i pādišāh wa-pādišāhzāda-i [...] Sulțān Abū l-Muzaffar Bāyezīd [...] ta’līf kard.

64 Ibid., f. 23b: har čand az taqdīr wa-qadā imkān-i hurūğ nīst ammā bi-mu'addā-i "wa-lā tulqū bi-aydīkum ilā l-tahluka" wa-šarr-i ihtirāz wāğib-ast wa-bi-qadr-i was' sa'y lāzim ča faḥwāy-i "laysa li-l-insān illā mā sa'ā"-rā išārat hamīn-ast wa-īn ma'nā bi-șūrat nayāyad illā az idrāk-i natāyiğ-i ḥarakāt-i ağrām-i samāwō ya'nı̄ sayr-i ağrām-i mustanīra dar aqsām-i ağsām-i mustadīra wa-ān dawāzdah dar dawāzdah-ast ki az șuwar-i zāyiḡāt-i țawālic

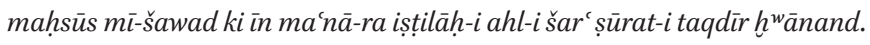

65 Nașīr al-Dīn al-Ṭūsī, Risāla dar Márifat-itaqwìm, Ms Istanbul, Süleymaniye, Ayasofya, 2809,

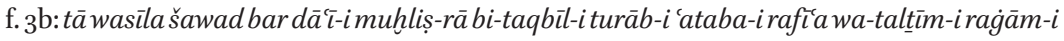
sudda-i manīa [...] al-sulțān b. al-sulțān al-sulțān Muhammad b. al-sulțān Murād hā̄n.

66 Aḥmad-i Dāīì, Muhtașar fì 'ilm al-tanğìm wa-márifat al-taqwīm (Risāle-i sī fașl), eds T. N. Gencan and M. Dizer, Istanbul, Boğaziçi Üniversitesi Kandilli Rasathanesi, 1984. 
found only among the books at the palace library also proves that it did not enjoy much circulation among the author's contemporaries. Thus, there is little doubt that the aim of Hițābì's Persian commentary on al-Ṭusī, which is much longer than the latter's text, was rather to show off his impressive knowledge and thereby secure the support of Mehmed II. He must have attained his desire, for immediately after he composed a voluminous horoscope for Mehmed II, a royal copy of which was produced in the year $885 / 1480$ by the imperial calligrapher and bookbinder, Giiyāt al-Dīn al-Muğallid al-Iṣfahānī. ${ }^{67}$

Hițābī seems to have secured his place in Bāyezīd II's entourage after the latter's immediate accession upon the death of Mehmed II in 886/1481. In the end of $887 /$ January 1483 he presented the new sultan, whom he described as being, among other things, wise and knowledgeable in sciences celestial and terrestrial ('ārif al-ma'ārif al-ulwiyya wa-l-sufliyya), a copy of his Risālat Tašrīh al-ālāt, together with an instrument for celestial observation. ${ }^{68}$ As Hițābī states in his treatise, the major objective of the work and the accompanying instrument is to test the accuracy of the three most preferred ziğs of the time. According to his calculations, he expects two conjunctions to happen in that year: the first between Mars and Jupiter, and the second between Saturn and Mars. Along with these two conjunctions, he also expects two full lunar eclipses to occur that year. However, as he says, the calculations based upon the $Z i \bar{g}-i$ Sa $\bar{\imath} d \bar{\imath}$ and the Zĭğ-i Ulug Beg were significantly different from those relying on the Zīğ-i İlhannī. ${ }^{69}$ Hițābi adds that as part of his research he completed in Istanbul a solar observation and identified a solar eclipse that occurred in ša bān-ramaḍān $887 /$ October $1482 .{ }^{70}$ While the fact of his solar observation in Istanbul by the late 880 s/early 1480 s is important in its own right, his undertaking to ensure the accuracy of astronomical data is even more significant, since

67 Ms Istanbul, Topkapı Palace Museum Library, Yeni Yazmalar, 83o, f. 264a. It is not the purview of this study to introduce the contents of this horoscope. For more details, see chapter 5 of my unpublished dissertation, Astrology in the Service of the Empire: Knowledge, Prognostication, and Politics at the Ottoman Court, 1450s-1550s, PhD dissertation, University of Chicago, 2016.

68 His remarks in the text hint that he also presents the sultan with an instrument for celestial observation: har āyina ālāt-i maw'ūd-rā bi yumn-i dawlat-i qāhira-i hậdrat-i pādišāhī bi-itmām rasānìda wa-kayfiyyat-i a'māl wa-waḍ'-i ān-rā darīn risāla mašrūḥ [wa] masțūr sāhta šud. Al-Hițābī's reference here to al-ma'ārif al-ulwiyya wa-l-sufliyya seems to be related to the classification of theoretical philosophy (al-hikma l-nazariyya) into sciences that deal with the knowledge of celestial ('ulwī) spheres (i.e. the quadrivium) and those that study the changes in the elemental sublunary (suffī) world.

69 Somi and Bagheri, "Risāla-i tašrīh al-ālāt," p. 183.

$70 \quad$ Ibid., p. 196. 
accurate astronomical data was exactly what practicing munağğims needed for precision in the time measurement required for astrological predictions.

Hitạāi does not divulge in his Risālat Tašrị̣h al-älät which of these three zĭğs he personally favors as a practicing munağğim, but as mentioned earlier, he did rely on the Zïg-i Sa ìd $\grave{\imath}$ in composing the taqwim for the year 894/1489. Only one taqwìm has survived that was indisputably penned by Hițābī Munağğim. While it is not the aim of this article to discuss in detail the political as well as social uses of the taqwim genre in the early modern Ottoman context, we should note that taqwims were instrumental in shaping, expressing, and even manipulating public opinion..$^{71}$ True, the majority of astrological predictions propounded in taqwims are generic and more often than not hackneyed; but it is the ceremonial nature of taqwims - in terms of both their production and presentation - that endowed them with a certain propaganda value. There is no surviving archival or pictorial evidence prior to the eleventh/seventeenth century as to the munağğims' presentation of taqwims to the sultan or the ruling elites, but the fact that their presentation essentially coincided with the coming of the new solar year (Nawrūz) and accompanying ceremonies hints at the symbolic value attached to the taqwims. Taqwims also seem to be generally, though not always, the products of collective effort, with lavishly gilded frames and beautifully colored diagrams. In most cases we have only one copy of a taqwim for each year; therefore the taqwim prepared by court munağğims was probably not put into circulation outside the palace. However, for certain years we have at least three different extant taqwims, which clearly indicate that court munağğims did not have a monopoly on the composition of taqwìms for the sultan. The gift register from the last decade of Bāyezīd II's reign confirms this last point, for in a given year different individuals might be given allowances on different dates in view of the individual taqwims they submitted.

If taqwims were not in wide circulation among the reading public, to what extent could they function as propaganda tools? The propaganda value of the taqwims stems from two interrelated aspects. First, the astrological predictions expressed in the taqwims may have been intended to articulate, and thus emphasize, certain political and social tensions of the time around the court. At times they demonstrably succeeded in manipulating the decision-making process of the ruling party. The close reading of annual astrological predictions in tandem with contemporary chronicles and historical narratives reveals that the astrological interpretations and forecasts of the munağğims in their

71 For a brief discussion of the political significance of taqwims in the Ottoman case see Fleischer, “Ancient Wisdom," esp. p. 235-236. 
taqwims were taken quite seriously, to the extent that campaigns were called off or battles were initiated on the basis of their annual reports. ${ }^{72}$ Moreover, that the phraseology of the astrological predictions in taqwims was occasionally imitated by contemporary poets and littérateurs provides valuable evidence suggesting that the discourse produced by the taqwims was indeed disseminated among the wider public, presumably orally rather than in written form. ${ }^{73}$

TABLE 2 Extant original taqwīms composed during the reign of Bāyezìd II.

\begin{tabular}{|c|c|c|c|c|}
\hline Year & Author & Dedicatee & Language & Zïğ used \\
\hline $894 / 1489$ & $\begin{array}{l}\text { Huițābī } \\
\text { l-Ḥusaynī }\end{array}$ & Bāyezīd II & Persian & $\begin{array}{l}\text { Rukn al-Āmulīs } \\
\text { tables }\end{array}$ \\
\hline $895 / 1490$ & Unspecified & Bāyezīd II & Persian & Ulug Beg Tables \\
\hline $895 / 1490$ & Unspecified & Bāyezīd II & Persian & $\begin{array}{l}\text { The Verified Ilkhanid } \\
\text { Tables }^{\mathrm{a}}\end{array}$ \\
\hline $897 / 1492$ & Unspecified & Bāyezīd II & Persian & Ulug Beg tables \\
\hline $900 / 1495$ & $\begin{array}{l}\text { 'Abd al-Karīm b. } \\
\text { Mawlānā }\end{array}$ & Bāyezīd II & Persian & Ilkhanid tables \\
\hline $900 / 1495$ & Unspecified & Bāyezīd II & Persian & Unspecified \\
\hline $901 / 1496$ & $\begin{array}{l}\text { Hamza b. 'Abd } \\
\text { al-Karīm }\end{array}$ & Bāyezīd II & Persian & $\begin{array}{l}\text { The Verified Ilkhanid } \\
\text { Tables }\end{array}$ \\
\hline $902 / 1497$ & $\begin{array}{l}\text { ‘Abd al-Karīm b. } \\
\text { Mawlānā }\end{array}$ & Bāyezīd II & Persian & Ilkhanid tables \\
\hline $902 / 1497$ & $\begin{array}{l}\text { Hamza b. 'Abd } \\
\text { al-Karīm }\end{array}$ & Bāyezīd II & Persian & $\begin{array}{l}\text { The Verified Ilkhanid } \\
\text { Tables }\end{array}$ \\
\hline $902 / 1497$ & $\begin{array}{l}\text { Nūr al-Dīn b. } \\
\text { Hamza }\end{array}$ & Bāyezīd II & Persian & $\begin{array}{l}\text { The Verified Ilkhanid } \\
\text { Tables }\end{array}$ \\
\hline
\end{tabular}

72 This discussion is also beyond the confines of this short article. For detailed examples see chapter 4 of Şen, Astrology in the Service of the Empire.

73 For example Dātī (d. 953/1546), one of the most prominent poets during the reign of Bāyezīd II, composed a burlesque almanac to express his satirical opinions on approximately 400 different anonymous people in a way reminiscent of the remarks of the munağğims' in their taqwìms. See Fuad Köprülü, Kayıkçı Kul Mustafa ve Genç Osman Hikayesi, İstanbul, Evkaf Matbaası, 1930, p. 6-7; Mehmed Çavuşoğlu, "Zati'nin Letayif'i II," Türk Dili ve Edebiyatı Dergisi, 22 (1977), p. 143-161. I would like to thank Michael Sheridan for bringing these studies to my attention. 
TABLE 2 Extant original taqwīms (cont.)

\begin{tabular}{|c|c|c|c|c|}
\hline Year & Author & Dedicatee & Language & Zīğ used \\
\hline $903 / 1498$ & Unspecified & Bāyezīd II & Persian & $\begin{array}{l}\text { The Verified Ilkhanid } \\
\text { Tables }\end{array}$ \\
\hline $903 / 1498$ & Unspecified & Bāyezīd II & Turkish & Unspecified \\
\hline $904 / 1499$ & Unspecified & Bāyezīd II & Persian & $\begin{array}{l}\text { The Verified Ilkhanid } \\
\text { Tables }\end{array}$ \\
\hline $904 / 1499$ & Unspecified & Bāyezīd II & Persian & Ulug Beg tables \\
\hline $904 / 1499$ & Unspecified & Bāyezīd II & Persian & Ulug Beg tables \\
\hline $905 / 1500$ & Unspecified & Bāyezīd II & Persian & $\begin{array}{l}\text { The Verified Ilkhanid } \\
\text { Tables }\end{array}$ \\
\hline $906 / 1501$ & Unspecified & Bāyezīd II & Persian & $\begin{array}{l}\text { The Verified Ilkhanid } \\
\text { Tables }\end{array}$ \\
\hline $906 / 15^{01}$ & Unspecified & Bāyezīd II & Persian & $\begin{array}{l}\text { The Verified Ilkhanid } \\
\text { Tables }\end{array}$ \\
\hline $907 / 1502$ & Unspecified & Bāyezīd II & Persian & $\begin{array}{l}\text { The Verified Ilkhanid } \\
\text { Tables }\end{array}$ \\
\hline $909 / 1504$ & Unspecified & Bāyezīd II & Persian & $\begin{array}{l}\text { The Verified Ilkhanid } \\
\text { Tables }\end{array}$ \\
\hline $909 / 1504$ & Salmān-i 'Ağam & Bāyezīd II & Persian & Ulug Beg Tables \\
\hline $909 / 1504$ & Unspecified & Bāyezīd II & Persian & $\begin{array}{l}\text { The Verified Ilkhanid } \\
\text { Tables }\end{array}$ \\
\hline $910 / 1505$ & Unspecified & Bāyezīd II & Persian & $\begin{array}{l}\text { The Verified Ilkhanid } \\
\text { Tables }\end{array}$ \\
\hline $911 / 1506$ & Unspecified & $\begin{array}{l}\text { Selīm b. } \\
\text { Bāyezīd }\end{array}$ & Persian & Ulug Beg tables \\
\hline $912 / 1507$ & Unspecified & Bāyezīd II & Persian & Ulug Beg tables \\
\hline $913 / 1508$ & Qāḍī-yi Bag̉dād & Bāyezīd II & Persian & Ulug Beg tables \\
\hline $913 / 1508$ & Unspecified & Bāyezīd II & Persian & $\begin{array}{l}\text { The Verified Ilkhanid } \\
\text { Tables }\end{array}$ \\
\hline $914 / 1509$ & Unspecified & Bāyezīd II & Persian & $\begin{array}{l}\text { The Verified Ilkhanid } \\
\text { Tables }\end{array}$ \\
\hline $915 / 1510$ & 'Abd al-Raḥmān & $\begin{array}{l}\text { Aḥmed b. } \\
\text { Bāyezīd II }\end{array}$ & Persian & $\begin{array}{l}\text { The Verified Ilkhanid } \\
\text { Tables }\end{array}$ \\
\hline $915 / 1510$ & Unspecified & Bāyezīd II & Persian & Ulug Beg tables \\
\hline
\end{tabular}




\begin{tabular}{lllll}
\hline Year & Author & Dedicatee & Language & Zĭğ used \\
\hline $916 / 1511$ & Yūsuf b. 'Umar & Bāyezīd II & Persian & $\begin{array}{l}\text { The Verified Ilkhanid } \\
\text { Tables }\end{array}$ \\
& & & Persian & $\begin{array}{l}\text { The Verified Ilkhanid } \\
\text { Tables }\end{array}$ \\
\hline
\end{tabular}

a After al-Ṭūsìs death in 672/1274 the astral experts at both the Maragha observatory and elsewhere kept working on rectifying the celestial data provided by the Zï̆ğ-i $\bar{l} h \hat{h} \bar{a} n \bar{\imath}$ and preparing its new editions. One of them was Šams al-Dīn al-Wābkanawī (d. 720/1320), who produced the Zï̆g-i muhaqqaq-i sultānn̄ (The Verified Ilkhanid Tables) by the turn of the eighth/ fourteenth century. It is not certain, however, whether the Verified Ilkhanid Tables cited frequently in different Ottoman taqwìms always refer particularly to al-Wābkanawīs work. Given that the Ottoman palace library, whose catalogue was prepared in 908/1502-1503, lacks a copy of al-Wābkanawī's zīğ, at least some of those "Verified Tables" cited in contemporary Ottoman taqwims might be referring to the different later editions of the Ilkhanid tables rather than to al-Wābkanawī's work. On al-Wābkanawī, see S. Mohammad Mozaffari, "Wābkanawīs Prediction and Calculations of the Annual Solar Eclipse of 30 January 1283," Historia Mathematica, 40 (2013), p. 235-261; Jamil Ragep, "New Light on Shams: The Islamic

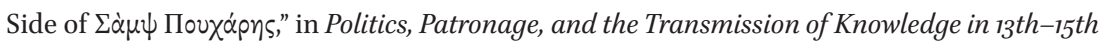
Century Tabriz, ed. Judith Pfeiffer, Leiden-Boston, Brill ("Iran studies", 8), 2013, p. 166-180.

Secondly, and more importantly, taqwims served as tools for bolstering royal claims and promulgating these claims among the elite audience attached to the court. The astrological predictions in taqwims are always biased in favor of the sultan, typically highlighting his unmatched strength, perseverance, and well-being regardless of actual historical circumstances. The taqwim dated 917/1512 is probably the most explicit example of such propaganda attempts. In this taqwìm, written just before Bāyezīd II would lose his life after years of fierce struggle with his sons for the throne, the anonymous munağǧim(s) cannot help but praise Sulțān Bāyezīd, strongly asserting in several places that the sultan will be resolute and long-seated upon his throne. ${ }^{74}$ These auguries may

74 MS Istanbul, Topkapı Palace Museum Library, Revan, 1711, f. 193a: dalälat kunad [...] bar hulüd-i salțanat wa-imārat wa-tazāyud-i hašmat wa-kāmrānīwa-taḍāuf-imuknat wa-dawlat wa-šādmānī-i hạdrat-i pādišāh-i Islām-panāh [...] wa-rāsih wa-țābit būdan bar sarīr-i salțanat wa-kāmrānī [...] bar taht-i dawlat wa-sarīr-i salțanat mustaqìm al-ḥäl wa-kāmrān buwand [...] hạadrat hallada zillahu dar tahtgāh-i ma'lüf țäbit wa-rāsih buwand [...] wa-dar 
well have been mere wishful thinking or meant to console the losing party, as the fortunes of the munağğim more or less depended on those of his patron. Nevertheless, given the fact that each and every taqwim producer aimed primarily at representing his patron (i.e. the reigning sultan) as the single most fortuituous and victorious ruler of the era, the production of a higher number of taqwims in a given period inevitably increased a ruler's opportunity to persuade his elite audience of the astrologically validated superiority of his ruling persona.

To return to the taqwìm of Hițābì for Bāyezīd II for the year 894/1489, he immediately begins by eulogizing Bāyezīd II on the occasion of the coming of the new year and expresses his good wishes to the sultan, whom he hails as the "caliph of the All-merciful, shadow of divine affection, strengthener of the world and religion, succour of Islam and all Muslims, glory of kings and sultans, victorious over his enemies by help of the Beneficent King." ${ }^{75} \mathrm{He}$ designates, based upon his computations utilizing his teacher Rukn al-Dīn's tables, that the revolution of the year will take place on Thursday night, 9 rabī‘ al-âhir 894/12 March 1489. He then enumerates the important astrological indicators and begins lengthy predictions on the fortunes of the sultan. According to his predictions, the glory and majesty of the sultan will remain untarnished, and his health and temperament balanced. The sultan will show sympathy to his subjects and bring civil order under his full control, but at times, especially during the winter, he will be anxious on account of his enemies and opponents. Hițābi then proceeds to elaborate on the fortunes of his subjects from various sectors, including viziers, dervishes, scholars, and many others. His judicium for the year ends, as usual, with predictions as to incidences of disease, meteorological conditions, crops and prices, and wars and battles. He then draws two tables for the horoscopes of the upcoming year: one on the basis of the Chinese-Uighur animal calendar and the other on the basis of his calculations using the astronomical tables. Then comes the section on the monthly elaboration of the calendrical information and accompanying astrological judgments. It is worth noting that the predictions he expresses in the monthly sections of his taqwim focus more on possible skirmishes and battles between Turks (atrāk), Arabs ( $\left.a^{\prime} r \bar{a} b\right)$, and Kurds $(a k r a \bar{d})$. It would not

nișf-i ah̆irr-i sāl az ba'ḍ-i mufattinān wa-ahl-i fitna wa-šarr-i fitna-hā wa-fasad-hā ba-zuhūr àyad ammā 'āqibat taskin yābad wa-dawlat wa-iqbāl wa-amwāl wa-hadam wa-hašam ziyāda ba-husūūl paywandad.

MS Istanbul, Topkapı Palace Museum Library, Bağdat, 310, 4a: halīfat al-rahmānn̄ zill-i

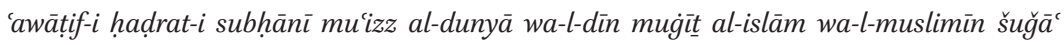
al-mulūk wa-l-salāținn al-manșūr 'alā l-a'dā' bi-nușrat al-malik al-mannān. 
be farfetched to relate these remarks to the repercussions of the then-ongoing Ottoman-Mamluk confrontation. Taking all these elements into consideration, Hițābī thus closely follows in his taqwìm the standard scheme and conventions of the genre.

The taqwìm of Hițābì is the earliest of around 30 surviving almanacs that were solely dedicated to Bāyezìd II. In certain years such as 904/1499 or 909/1504 we have at least three different, original taqwims drafted by separate munağğims. It is beyond the scope of this study to compare the contents of those different taqwims from a single year, but we can safely say that although these taqwims have substantial differences generated by the use of different $z i \grave{g} s$, the predictions they make attest to their common "sultanocentrism" and intention to promulgate Bāyezīd's divinely validated rule through a rich imperial titulature.

In terms of the number of extant taqwìms, the court of Bāyezīd II once again considerably outstrips those of his predecessors and successors. There are fewer than eight extant taqwims that were produced in the 30-year reign of Mehmed II, and no more than five for that of Selīm I. The time of Süleymān is also not significantly different, as the number of surviving taqwims from his 46 years of rule $(926 / 1520-974 / 1566)$ seems to be no more than 18 .

The disproportionate ratio of extant taqwims could be just a matter of preservation; however, as we will see in more detail, the higher number of taqwims is clearly the product of Bāyezīd II's keen personal interest in astral sciences, such that contemporary scholars often considered it a lucrative business and even a career opportunity to dedicate to him a taqwim and/or a relevant astrological/astronomical text. One good example is Qāḍi-yi Bag̀dād, who decided to approach Bāyezìd II for the first time in the year 913/1508 by presenting him with a taqwim. ${ }^{76}$ As also manifest through the famous gift register, besides those court munağğims whose primary task was to prepare the annual astrological predictions, there were around 15 extra-courtly agents who received allowances in return for the taqwìms they presented. For Bāyezīd II the annual predictions expressed through taqwims were so important that, as we will see in more detail below, the failure of a court munağğim to report his forecasts was sufficient reason to dismiss him from service.

Although many of the court munağğims and those aspiring to that status received the benevolence of Bāyezīd II whenever they presented him with a

76 The unique copy of this taqwim is available in London, British Library, Or. 6432, ff. 26b$5^{2}$ b. The famous register of gifts and payments also records his name as the recipient of 1,500 aspers on April 25, 1508 for his debut presentation of the sultan with his taqwim. See Atatürk Kitaplı̆̆ı Muallim Cevdet O. 71, p. 263. 
taqwim, there are two important figures whose relationships with the sultan were demonstrably of a special character. The first one, who is unhelpfully named in the register as simply Sayyid Munağğim, seems to have had a status superior to all the other court munağğims. Unlike many others, he was not only rewarded whenever he presented a taqwim; in certain years, he received payments and/or robes of honor on four or five different occasions, most of which are unfortunately not specified. ${ }^{77}$ On several occasions (again unspecified) he was even paid 7000 aspers, almost equal to the payscale of provincial governors and other servants of higher rank. The amounts he received when he presented a taqwim were also always higher than other munağğims. Where he was given 1500 aspers, the payscale of others ranged between 500 and 1000 aspers. Moreover, he was once presented a garment on the occasion of the loss of his son, suggesting that he must have had a close relationship with the sultan, for it was usually Bāyezīd's closest companions who received gifts upon such occasions of death or marriage.

Apart from the information gleaned from the gift register, we know next to nothing about Sayyid Munağğim, which makes his personality all the more intriguing. Although he was an important courtier of the sultan, as indicated by the amounts and occasions of the gifts he received, none of the biographical sources or contemporary narratives mention his name, with the exception of a single waqf record, dated 894/1489, documenting his estates in the Eyüp neighborhood of Istanbul. ${ }^{78}$ The lack of contemporary information as to an important courtier of a sultan suggests that sayyid munağğim was rather the epithet, not the real name of the person in question. It should be recalled that the proper name of the Timurid sayyid munağğim was Muhammad al-Husayn. In a similar vein, in his surviving autobiographical piece, the munağğim of Bāyezìd's eldest son Ahmed in Amasya, describes his master from Shiraz as the chief of the munağğims (sayyid al-munağğim). ${ }^{79}$ Therefore what sayyid munağğim stands for was likely a label attributed at different times to different munağğims either by themselves, their peers, or the court, whose prestige and erudition were deemed superior to their contemporaries. There were other epithets as well frequently deployed by astral experts in the eighth/fourteenth and ninth/fifteenth centuries, such as šams al-munağğim used by al-Wābkanawī

77 Atatürk Kitaplığı Muallim Cevdet O. 71, passim.

78 Ömer Lütfi Barkan and Ekrem Hakkı Ayverdi, İstanbul Vakıfları Tahrir Defteri: 953 (1546) tarihli, Istanbul, Baha matbaası, 1970, p. 155.

79 Ms Istanbul, Süleymaniye, Ayasofya, 3635 , f. 3 a. 
or 'imād al-munağğim adopted by Maḥmūd b. Yahyā l-Ḥasan al-Kāšì, the author of the famous Mīrzā Iskandar horoscope. ${ }^{80}$

Could the Sayyid Munağğim active at the court of Bāyezīd II through the end of his reign be Hițābi himself? There is a slight possibility that the two were the same, for the waqf record about Sayyid Munağğim that dates back to $894 / 1489$ establishes at least that the two were active at the same time. Yet, we should also keep in mind that Hițābi never refers to the epithet in the surviving copies of his original texts, so we cannot easily assume their identity in the absence of new and conclusive evidence.

Next to this Sayyid Munağğim, the other important expert in 'ilm al-nuğūm who had a very special status at the court of Bāyezīd II was Mīrim Čelebī (d. 931/1525). He is a relatively better-known figure due to his descent from Mūsā Qàḍizāda-i Rūmì (d. after 844/1440) and relation to 'Alī Qūušğì (d. 879/1474), the two leading figures of the ninth/fifteenth-century mathematical-astronomical school of Samarkand. ${ }^{81}$ Thanks to his ancestral prestige, as early as the early 89os/late 1480s Mīrim started to receive a salary as a member of the zawäidhürān class, peculiar to the sons of the prestigious 'ulamä' families. ${ }^{82}$ Upon completing his madrasa education likely in the late 89os/early 1490 s, he started teaching at several mid-level madrasas in Bursa and Edirne. Around this time, he was called by Bāyezīd II to be his private tutor and instruct him in the

8o On šams al-munağğim, see the works of Mozaffari and Ragep cited above. For 'imad al-munağğim see Fateme Keshaverz, "The Horoscope of Iskandar Sultan," Journal of Royal Asiatic Society, 2 (1984), p. 197-208. Interestingly, one of the taqwims composed in plain Turkish in the year 937/1531 and dedicated to Sulțān Süleymān was signed by another selfproclaimed al-sayyid al-munağğı̀m from Tokat (northeastern part of Anatolia), whose actual name was apparently Ibn Sayyid Tāğ. Ms Istanbul, Topkapı Palace Museum Library, III. Ahmed, 3497, f. 3a. Given the fact that one specific register of payments from the early 920s/late 1520 lists the son of Sayyid Munağğim at Bāyezīd II's court as the then chief munağğim, we can safely argue that by the time this Ibn Sayyid Tāğ composed his almanac, the sayyid munağğim at Bāyezīd's court must have already passed away. All things considered, the chief (i.e. sayyid) munağğim during the last decade of Bāyezīd II's reign must have been an individual different than those so styled at the Timurid realm or the time of Süleymān.

81 See İhsan Fazlıoğlu, "Mīrim Čelebī: Maḥmūd ibn Quṭb al-Dīn Muhammad ibn Muhammad ibn Mūsā Qāḍizāde," in The Biographical Encyclopedia of Astronomers, dir. Thomas A. Hockey, New York, Springer, 2007, p. 788-789. For Qāḍīzāda and 'Alī Qūšğī, see F. Jamil Ragep, "Qāạīzāda al-Rūmī: Șalāḥ al-Dīn Mūsā ibn Muhammad ibn Maḥmūd al-Rūmī," in ibid., p. 942; İhsan Fazlıoğlu, "Qūshjī: Abū al-Qāsim 'Alā' al-Dīn 'Alī ibn Muhammad Qushči-zāde" in ibid., p. 946-948.

82 Ömer Lütfi Barkan, "Ayasofya Camii ve Eyüp Türbesinin 1489-1491 yıllarına ait Muhasebe Bilançoları," Istanbul Üniversitesi İktisat Fakültesi Mecmuası, 23/1-2 (1962-1963), p. 358. 
mathematical-astronomical sciences (al-ulūm al-riyädìyya). ${ }^{83}$ It is not certain when exactly the student-tutor relationship between the two began, but we have evidence that from $c a$ 90o/mid-149os onwards Mīim was in close proximity to Bāyezīd II. As documented by a catalogue record of a private auction held in the 199os, Mīrim Čelebī even produced two annual almanac-prognostications, one for the year 900/1495, the other for the year 904/1499. ${ }^{84}$ Although not listed in the voluminous gift register, another minor payment register corroborates that he once received 1,000 aspers for a taqwim he presented in the early tenth/sixteenth century. ${ }^{85}$

Around the year 904/1499, Bāyezīd asked Mīrim Čelebī to write a commentary on the Ulug Beg tables to clarify its ambiguous points. In the introductory passages of his commentary, Mīrim outlines the attempts of his own master Huwāğa 'Ațā' Allāh (d. 886/1481) and of his grandfather 'Alī Qūščī, who tried to compose an expositional work on the concepts and parameters mentioned in the original Ulug Beg tables. ${ }^{86}$ In his dedication remarks, Mīrim lavishly praises Bāyezìd II, among other ascriptions, as the most perfect and enlightened of the caesars of the world, as powerful as Alexander, who orders the affairs of the world according the rule of Farīdūn and the precepts of Plato, and as the messianic saviour of the end times (mahdi-yi ăhir-i zamān). ${ }^{87}$ He repeats similar remarks in other parts of the text where he identifies Bāyezīd as the pādišăh of the inhabited world and the prophesied world ruler (șăhib-qirān). ${ }^{88}$ Similar titulature is used in his works on astronomical instruments he composed and presented to the sultan in the first decade of the tenth/sixteenth century. For instance, in his work on the uses of the sine quadrant, Mīrim expresses his gratitude toward Bāyezīd II who is, as he puts it, chief among prophesied world rulers (wāsita-i 'iqd-i șăhib-qirānī) and the messianic savior of the end times (mahdì l-rahma fì ăhir al-zamān). ${ }^{89}$ Even though Mīrim does not elaborate in his works on the astral grounds of the titles he ascribes to Bāyezīd, his

83 Ṭā̌sööprüzāde, al-Šaqā̉iq al-nu'māniyya, p. 198.

84 I found this information at http://www.islamicmanuscripts.info/reference/books/Sothe bys-19941019/Sothebys-19941019-109-128.pdf. Unfortunately, both of these taqwims are now in private collections and thus not accessible for research.

85 Topkapı Palace Museum Archive D. 9600.

86 MS Istanbul, Süleymaniye, Ayasofya, 2697, f. 2a-2b. This Hुwāğa 'Ațā’ Allāh must be the Mawlānā 'Ațā̄' Allāh Kirmānī whom Țāšköprüzāde introduces as an expert in taqwīm and zĭğ. See Țāšköprüzāde, al-Šaqā’iq al-nu'māniyya, p. 135.

87 MS Istanbul, Süleymaniye, Ayasofya, 2697, f. 2b: akmal wa-a'qal-i qayāșira-i 'ālam-i Dū l-qarnayn-šawkatì ki ba-ḥukm-i Farīdūnī wa-ḥikam-i Aflāțūnī asbāb-i ğihāngīrī sāhnt.

88 Ibid., f. 263 b.

89 MS Istanbul, Topkapı Palace Museum Library, Hazine, 176o, f. 4ob. 
resort to these concepts as a close companion of Bāyezīd and a prominent expert of astral sciences is quite telling as to the extent of the discussion on the vocabulary of sovereignty in the late ninth/fifteenth and early tenth/sixteenth century Ottoman context. ${ }^{90}$

The entries of the voluminous gift register covering the period 909/1503918/1512 likewise show that Mirim must have been a close companion to the sultan, as Bāyezīd sponsored his wedding in 911/1505 and later gave Mīrim's wife several items of clothing as a gift in the year 915/1510. ${ }^{91}$ Idrīs Bidlīsì, another contemporary courtier of Bāyezīd II, also acknowledges the great esteem in which Bāyezīd II held him..$^{92}$ Further evidence for Mīrim Čelebī's close connection to Bāyezīd II is the fact that during the pro-Selīm rebellions in the capital in late 917/1511 he was among those individuals who were targeted by the proSelīm factions, along with the chief military judge Mu’ayyadzāda (d. 922/1516), the chancellor Tăğīzāda Ğa far Čelebī (d. 921/1515), and the chief physician Āhī Čelebī (d. 930/1524), on the grounds that they supported Bāyezìd's favorite son Ahmed against Selīm. ${ }^{93}$

In addition to the taqwims, the commentary on the Ziğ-i Ulug Beg, and the works on various astronomical instruments, Mīrim Čelebī composed at least two treatises on two specific fields of astrology, namely elections (ihtiyārāt) and interrogations (masäil). Although the surviving copies of these works have no colophons that could help us reconstruct the dates of their composition, Mīrim likely compiled them after the reign of Bāyezīd II, as they do not include dedications to the sultan. In fact, Mīrim's astrological works are geared more towards practicing astrologers who needed to advance their skills in the relevant techniques. In his work on interrogations (Ta tî̀rāt dar masāill), for instance, Mīrim handles all possible questions a customer might ask a practicing munağğim. In so doing, Mīrim shows his vast knowledge of the subject and frequently cites such names as Vettius Valens (Valis), Hermes Trismegistus, and Māšāallāh as the major authorities on this science. Moreover, he encourages

9o On the debates on the vocabulary of sovereignty in the post-Timurid realm see Christopher Markiewicz's dissertation, which finds it to have significant receptions in the late-fifteenth and early-sixteenth century Ottoman political and intellectual context: Markiewicz, "The Crisis of Rule," esp. p. 311-341.

91 Atatürk Kitaplığı Muallim Cevdet O. 71, p. 159: in'ām bi-Mawlānā Mìrim Čalabì barāy-i harğ-i 'urs-i ḩūd fì 26 minhu (i.e. 26 ğumādā l-āhira 911/24 November 1505); ibid., p. 368 :

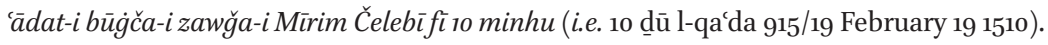

92 Vural Genç, Acem'den Rum'a: İdris-i Bidlisinnin Hayatı, Tarihçiliǧi ve Heşt Behişt'in II. Bāyezìd Kısmı (1481-1512), p. 880: bi-șuḥbat-i mağlis-i humāyūn az sāiri-i 'ulamā mumtāz-ast.

93 Çağatay Uluçay, "Yavuz Sultan Selim Nasıl Padişah Oldu II," İstanbul Üniversitesi Edebiyat Fakültesi Tarih Dergisi, 7/10 (1954), p. 117-142, esp. p. 120-121. 
his readers to consult authoritative texts in this discipline such as Qașrānī's ( $f$ l. probably in the eighth/ninth century) Kitāb al-Masäil for further reading. $\mathrm{He}$ also mentions astrolabes and quadrants as major tools in the practicing munağğim's toolkit, and argues that one of the most important reasons for inaccurate predictions on the part of munağğims are defects in these instruments that impair their accuracy. ${ }^{94}$

\section{Bāyezīd II as Student of 'ilm al-nuğūm}

Up to this point I have tried to sketch the extent of Bāyezīd's patronage of the munağğims based primarily upon archival salary registers, taqwīms, and related treatises of select names presented to the sultan. There are still other sources, however, that shed light upon the sultan's deep interest in the science of the stars. The private correspondence between Bāyezīd II and his munağğims as well as other contemporaries, albeit somewhat limited, adds to the image of the sultan as a dedicated observer of heavenly configurations. Indeed, the Archive of the Topkapı Palace Museum, the main repository of pre-nineteenth-century loose documents (awrāq), such as copies of letters, imperial orders, petitions, and other records, house a small amount of reports and memos written by the munağğims and other diviners at court. In this regard, a student of earlymodern Ottoman history particularly interested in the practical and political uses of astrology during the ninth/fifteenth and tenth/sixteenth centuries is not as fortunate as the historians of contemporary European courts, who have at their disposal a richer body of documenti astrologi.

The scarcity of confidential astrological and similar writings in the Ottoman archives, at least for the period in question, may lead one to think that the role of the munağğims and/or other diviners should not be overstated. However, one should always keep in mind the oral nature of astrological counseling. This phenomenon has already been discussed in the relevant European historiography, which has found that astrological predictions were often expressed verbally; astrologers were in close proximity to their patrons, so written explanations might turn out to be dangerous in the hands of rival factions. ${ }^{95}$

94 MS Istanbul, Süleymaniye, Bağdatlı Vehbi, 2005, f. 10a: dar márifat-i čìz-hā ki hațā dar masā̄il az ān-ğihat wāqi mì-šawad wa-ān čahār-ast awwal hațāa dar masāil bi-sabab-i hațāa dar ālat [...] čūn usțurlāb wa-rub'mī-bāšad.

95

Azzolini, The Duke and the Stars, p. 4. Carey also points to the fact that most of the horoscopes are written only as tables, without accompanying explanations, which were probably expressed on the spot. See Hilary M. Carey, "Astrology at the English Court in the 
In fact, the same concern is also found in a few surviving Ottoman documents. For example, in his letters in which he forecasts certain political issues of the time based upon his expertise in geomancy, Haydar-i Rammāl (geomancer), the key diviner at the court of Süleymān, reminds the sultan that his predictions should be communicated orally. ${ }^{96}$ On one such occasion, the geomancer reiterates à la Mission Impossible that his document should be destroyed immediately after reading. ${ }^{97}$ In that sense, it is not at all surprising that we find few private predictions in the archives for the period in question. There are extant, nevertheless, two curious petitions from the time of Bāyezìd II attesting to his relationship with his munağğims as well as to his great interest in hearing their calculations and interpretations.

In the first document, which is undated but located in the folder of the written communications from the time of Bāyezìd II, the anonymous munağğim asks in Persian for the sultan's sympathy and forgiveness because, as he admits, he has recently failed to present him with a taqwim..$^{98} \mathrm{He}$ raises two reasons for his recent inattentiveness. Firstly, he says, his attention has lately been focused on medicine rather than astrology. Secondly and more strikingly, the anonymous munağğim maintains that as he becomes older and death draws near, it excites more grief and uneasiness to deal with the stars, especially with the judicium (ahkām). In the last part of this petition the anonymous munağğim desperately pleads with the sultan to reemploy him in his service. ${ }^{99}$

Besides showing quite intriguingly that some of the practicing munağğims had deep suspicions about the epistemological validity and religious permissibility of their own craft, the petition is a clear proof that Bāyezìd II inquired after, and waited impatiently for, the astrological counseling of his munağğims. Since failing to produce the annual astrological predictions in a timely manner potentially entailed a munağğim's loss of position, Bāyezīd II must have deemed the standard astrological counsel a quite serious matter indeed.

Later Middle Ages," in Astrology, Science, and Society: Historical Essays, ed. Patrick Curry, Woolbridge, Boydell Press, 1987, p. 41-56.

96 Fleischer, "Seer to the Sultan," p. 295.

97 MS Istanbul, Topkapı Palace Museum Archive, E. 1698: sa'ādetlü sulțānımiñ mürüvvetiniñ

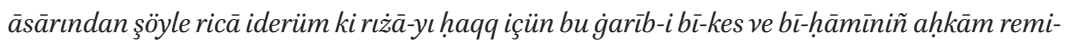
llerimi bir kimesneye göstermeyüb muțāla'a qıldıkda nihān ve maḥv idesüz ki bir kimesne ahvoāle muțtalic olmaya.

98 MS Istanbul, Topkapı Palace Museum Archive, E. 10159/145: dar ìn ayyām muyassar našud ki bi-istihrāă-i taqwīm mašğ $\bar{u} l$ šawad.

99 Ibid:: az čand ğihat yakī az ištig̀ăl bi-muțāláa-i țibbiyya ammā mānici kullì ān-ast ki ìn kamina-rā waqt-i irtiḥāl nazdīk-ast wa-ištiḡāl bi-nuğūmiyyāt siyyamā bi-ahkām-aš mustalzim-i qasāwat-i qalb-ast. 
In the second petition, another undated document from the same folder, likely written by the same munağğim based on similar language and handwriting, the anonymous munağğim says that, to the best of his knowledge, the Zìğ-i Ulug Beg, Nașîr al-Dīn al-Ṭūsìs Tahrīr al-Mağisțtì and a sizeable astrolabe as well as the horoscopes of the exalted sultan and his sons Qorqud and Ahmed are located in the imperial treasury (hizāna). ${ }^{100}$ The anonymous author of the petition asks for these books and the instrument to be given to him for his use, and adds that if the horoscopes are not available he can produce new ones if he is told the birth dates of the sultan and his sons. ${ }^{101}$

How did this anonymous munağğim know that the books and the tools he requested were in the imperial treasury? Perhaps he heard it from one of his peers who had found an opportunity to work there; or perhaps he had access to the catalogue of the royal palace library produced in the year 909/15021503 by the chief librarian, 'Ațūfì (d. 948/1541), assuming that the anonymous munağğim wrote his petition after this date. Indeed, 'Ațūfì's inventory, which lists the names of around 5700 volumes and 7200 titles in various branches of knowledge housed in the imperial treasury, indicates that the items requested in the petition, apart from the horoscopes of Qorqud and Ahmed, were available at the time in the imperial palace library. ${ }^{102}$

'Ațūfi's inventory is particularly rich in terms of those works belonging to the Islamic corpus astronomicum and corpus astrologicum. In addition to numerous copies of several important works on the planetary theory and the tradition of 'ilm al-hay'a, such as al-Ṭūsìs Tadkira and Tahrīr al-Mağisțī, Quțb al-Dīn Šīrāzī’s (d. 710/1311) al-Tuhfa l-šāhiyya, and Qāḍīzāda's commentary on Čaġminn's Mulahhas, which are not the particular concern of this paper, the library houses, among other things, the following: at least 14 copies of al-Tūsì's Risāla-i Si fașl and its commentaries as well as its Arabic translations, 12 copies of the Ż̌̆g $i \bar{I} l h \bar{a} n \bar{\imath}$ corpus, including the later editions and commentaries such as Zīğ-i Hāāānì of Nizāàm al-Dīn Nīsābūrì (d. 729/1328-1329), eight copies of the Ziğ-i Ulug Beg and contemporary commentaries including that written by Mīrim Čelebī, nine copies of the (pseudo-)Ptolemy's Centiloquium (Kitāb al-Tamara) and its Persian translations, five copies of Abū Ma šar's

\footnotetext{
100 MS Istanbul, Topkapı Palace Museum Archive, E. 10159/6.

101 Ibid.: kitāb-i ż̆ğ-i Ulug̉ Begi wa-kitāb-i Mağisțī wa-usțurlāb-i tām bā-țāli'-i hadrat-i ālampanāhì bā-țālici mawlūd-i sulțān Qurhūt wa-țâlici mawlūd-i sulțān Aḥmad dar hizāna būda amr farmāyand ka badīn kamina badahand wa-agar țāli-hā ma'lūm nabāšad tārīh-i wilādat-hā taslīm nimāyand tā ba'd az istihrāğ kayfiyyat-i țāli'i-i har yak-rā čunānča az dalāyil-i nuğūmì ma'lūm šawad ba-'arḍ rasānīda šawad.

102 Ms Budapest, Library of the Hungarian Academy of Sciences, Török, F 59.
} 
various treatises including that on historical conjunctions, and many other key texts, including the Kitāb al-Tafhìm of al-Bīrūnī (d. ca 442/1050), ${ }^{103}$ Kūšyār b. Labbān's Muğmal al-ușūl fi ạ̣kām al-nuğūm (aka Kitāb al-madhal fi șinā'at ahkām al-nuğūm), ${ }^{104}$ al-Qașrānì's Kitāb al-Masāill, ${ }^{105}$ and Faḩr al-Dīn al-Rāzìs (d. 6o6/1209) al-Ihtiyārāt al-Alä'iyya, favored particularly by those interested in the techniques of interrogations and hemerology. The inventory also lists the horoscopes of Mīrzā Iskandar Sulțān b. 'Umar Šayh (d. 818/1415), Meḥmed II, and Ğem Sulțān, in addition to that of Bāyezīd II.

One of the striking characteristics of the inventory, at least for the section on books about astronomy and astrology, is the number of treatises and copies produced contemporaneously. In addition to almost all the works of Hițābi l-Ḥusaynī and Mīrim Čelebī that are written before 908/1502-1503, the library includes the Zīğ-i Muğmal of Mawlānā Kūčak which he had presented Bāyezīd II in the early 88os/late 1470s in Amasya ${ }^{106}$; the treatise of Munağğim Bālì (d. after 886/1481) on quadrants and that of Afazāda ( $f$ l. late ninth/fifteenth century) on astrolabes, both dedicated to the sultan; ${ }^{107}$ and an anonymous commentary

103 See al-Bīrūnī, The Book of Instruction in the Elements of the Art of Astrology by Abu'l-Rayhāan Muhammad ibn Aḥmad al-Bīrūnī, transl. Robert Ramsay Wright, London, Luzac, 1934.

104 See Kūšyār b. Labbān, Kūshyār ibn Labbān's Introduction to Astrology, ed. and transl. Michio Yano, Tokyo, Tokyo University of Foreign Studies ("Studia culturae Islamicae", 62), 1997 .

105 Not much is known about this third/ninth-century astrologer, but given that there are four copies in the palace library of his Kitāb al-Masā̄il and that Mīrim Čelebī particularly cites him in his own treatise, al-Qașrānī's text was an important part of the Ottoman astrological canon. Faḩr al-Dīn al-Rāzī also refers to him among other astrological authorities from the early Abbasid period. See MS Istanbul, Süleymaniye Library, Bağdatlı Vehbi, 2005, f. 47b: ìn qadr dar márifat-i ạ̣kām kifāyat bāšad wa-agar kasī ziyāda az ìn hnwāhad ba-muhtașar-i Qașrānī ki bi-masāill-i Qașrānī mašhūr-ast murāăáat nimāyad.

106 Ms Istanbul, Topkapı Palace Museum Library, Revan, 1713. There is a possession statement on the title page demonstrating that the copy was in the possession of Mu'ayyadzāda by ramaḍān-šawwāl 881/January 1477. Mawlānā Kūčak dedicated the book when Bāyezīd was still a governor in Amasya. Kūčak still identifies him as the "pole of the orb of prosperity" (quțb falak al-iqbāl) and as a great ruler who is illuminated with the knowledge of the most exalted sciences, which are, as he says, the religious sciences, 'ilm al-hay'a, and 'ilm al-nuğūm.

107 For Munağğim Bālī’s treatise see Ms Istanbul, Süleymaniye, Ayasofya, 2588. Bālī also refers to Bāyezīd's pietistic and learned interests in his dedication remarks by defining him as "key to the treasury of spiritual matters" (kilīd-i dar-i ganğ-i ma'ānī) and "diver in the sea

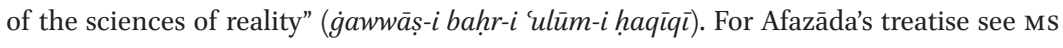
Istanbul, Süleymaniye, Ayasofya, 2641. In line with the general contemporary attitude to 'ilm al-nuğūm, Afazāda touches upon the importance of this knowledge for pietistic, 
(titled Mi'yār-i âftāab) on al-Tiusis's treatise on the use of astrolabes that was presented to the sultan in the year 896/1490-1491. ${ }^{108}$ Though not particularly cited in the inventory, 'Abd al-Salām al-Muhtadī also presented in dū l-higğğa 908/ June 1503 his Ma'rifat haqiqqat mawdū'at al-kawākib, which he translated from Hebrew upon the sultan's personal request (bi-talqin al-sulțān). ${ }^{109}$ Interestingly, however, none of the taqwīms, even those bearing the seal of Bāyezìd II, are listed in the inventory. Although the reasons for their omission in the cataloguing of the imperial library are not clear, the ephemeral nature of the taqwims might have resulted in their being perceived differently than regular books.

The anonymous munağğim's request to borrow materials from the treasury and 'Ațūfi's inventory raise two questions: to what extent was this library a working one, and what can the library's inventory tell us about Bāyezìd's own reading preferences? As the second petition clearly shows, the munağğims had access to the books and tools stored in the treasury. That the inventory includes a number of treatises and copies presented to Bāyezīd II when he was in Amasya as the governor, like Mawlānā Kūčak's Zïğ-i muğmal or Hiṭābī's Ğāmic al-qismayn, also suggests that Bāyezīd II must have carried those books from his court in Amasya to the imperial palace. Yet we cannot assume that each and every book that bears his seal and is thus listed in the inventory of the royal library was actually read by the sultan himself. There are, however, several copies in manuscript libraries that have, in addition to the standard oval seal of Bāyezīd II, inscriptions on the title pages indicating that the book in question was the personal possession of the sultan (șạhibuhu l-sultān Bāyezìd hāan). Among these books personally possessed and likely studied by Sulțān Bāyezìd II are a number of astrological and astronomical works such as al-Ṭusì's Sì faṣl and the Zĭğ-i İlhānni, ${ }^{110}$ a treatise on the use of astrolabes titled Lubāb al-usțrlāb, 'Alī b. Aḥmad al-Balhì's Kitāb Madhnal ậkām al-nuğūm, an introductory work on the general principles of astrology, a mağmū'a including

astronomical, and astrological purposes. He also points to calculating planetary positions (taqwim-i kawākib) and the ascendants (țawāli $)$ as being among the primary operations one can carry out with the astrolabe. In his dedication remarks to Bāyezīd, he refers to him as șăhib-qirān and praises his unique knowledge of prophetic wisdom (al-mutafarrid bi-l-hikma l-luqmāniyya).

108 See ms Istanbul, Süleymaniye, Ayasofya, 2677.

109 See ms Istanbul, Topkapı Palace Museum Library, III. Ahmed, 3495, f. 88a: fa-qad naqala hādihi l-risāla min al-'ibrānī ilā l-'arabì l-'abd al-ḥaqür 'Abd al-Salām al-Muhtadī bi-talqīn al-sulțān abbada Llāhu dawlatahu.

110 I would like to thank Zeren Tanındı, who notified me of the Zĭğ-i İlhānī copy that has Bāyezīd's possession marks and is now housed in the Turkish and Islamic Arts Museum in Bursa. 
(pseudo-)Aristotle's Risālat al-Ġālib wa-l-mag்lūb-a treatise, popular especially among taqwim writers, on a prognosticative technique as to the outcome of a battle between two parties-, and another mağmū $a$ consisting of several treatises on astronomical instruments.

Did Bāyezīd study these texts while Mīrim Čelebī was teaching him the mathematical sciences (al-ulūm al-riyandiyya), or is it rather the case that Bāyezīd II would have read them alone, if read them he did? Unfortunately, the copies do not include useful marginalia or other meta-textual evidence that could shed light on how Bāyezīd himself studied these texts. Mīrim's own works also do not yield any clues about this aspect of the story. Nevertheless, that these books bear marks of the sultan's desire to keep them on hand for his personal consultation still suggests Bāyezīd's reading tastes. Besides this physical evidence, moreover, there are also a number of contemporary testimonies that reveal the nature of his reading preferences and intellectual aspirations.

The most intriguing of these contemporary testimonies to Bāyezīd's genuine interest in the study of heavens, as well as in alchemy, is an anonymous letter located in the archives of the Topkapı Palace Museum. ${ }^{111}$ In this undated letter that casts light upon the learned interests of the sultan, the anonymous author, who speaks in the idiom of a highly self-confident and assertive Sufi shaykh using alchemical jargon, writes that he recently heard the Ottoman sultan Bāyezīd was sinking his teeth into learning 'ilm al-hay'a, along with another formidable branch of 'ilm-i hikmat which he does not identify. ${ }^{112}$ In his opinion, however, Bāyezīd lacks acumen and his attempts to master these sciences were made solely on the basis of personal experience (tağriba). It is the author's desire to remind the sultan, whom he characterizes as a zealous servant in the path of Islam, of the transitory nature of life and the insignificance of worldly possessions. ${ }^{113}$ He then says that he has decided, in accordance with the portents in his dream, to send Bāyezīd one of his disciples to inculcate in him his real essence. The training should continue, the shaykh argues, until Bāyezīd attains the spiritual stage that his disciple has already reached at the hands of the master. Once Bāyezīd reaches that stage, then he, the author, will write

\footnotetext{
111 MS Istanbul, Topkapı Palace Museum Archive, E. 6172.

112 Ibid.: malik-i memleket-i Rūmiyye kim Āl-i 'Oșmāniyeden Sulțān Bāyezīd'dür şöyle istimā' olundı ki șan'at el-hey'ete ve bir hikmete ki hikmeti muhībdür țālmış ammā tecrübe tarīqiyleymiş vuqüf yog̉imiş.

113 Ibid.: benim üzerime lāzım oldu ki anā şefqat idub tenbīh eyleyem [...] metāc-i dünyā qalïldür biz bundan raḥil üzerineyüz istihāre itdüm hayr şunda gördüm ki şākirdlerimden birini gönderem vara anā māddesin ta lìm eyleye.
} 
a type of talisman for the sultan to help him gain access to secrets. ${ }^{114}$ Finally, in explaining why he absents himself from Bāyezīd's presence and rather prefers to send his disciple to train the sultan, the author says that he is afraid of interacting with the sultan, and argues further that wise men should refrain from consorting with rulers, for the ruler may abuse the knowledge imparted because they are not like wise men. ${ }^{115}$

Besides providing evidence for how relationships between Sufis and sultans were initiated and negotiated, and alluding to contemporary discussions on competing epistemologies of knowledge, this letter clearly shows that Bāyezīd's preoccupation with different branches of the hikmat tradition like the science of the stars and alchemy was well attested to in his own time by contemporary figures. The way the anonymous author uses the concept of tagriba (experience) is also worth pondering. Although this concept has various connotations in medieval Islamic thought, it is usually associated among Sufi circles with a special, intuitive mode of knowing. ${ }^{116}$ However, the author of this short report, despite speaking with a strong Sufi tone, belittles it, as this is, as far as he has heard, how Bāyezīd is accustomed to studying 'ilm al-hay'a and the other formidable branch of hikmat left unspecified. What the author means by the term tağriba thus seems to be related to a kind of knowing based not on intuition or personal inspiration, but rather on bookish learning, observation, and perhaps even empirical study.

As to such a culture of observation and experiential knowledge, a Jewish physician at the court of Bāyezìd II provides captivating details. Around the year 905/1500, Moses ben Judah Galeano, or Mūsā Ğālīnūs, a Jewish physician at the court of Bāyezīd II who had devised a spring-wheeled robot and composed an astronomical book while he was in Istanbul in the sultan's service, compiled a Hebrew-language compendium of knowledge entitled Ta'allumot hohmah (Puzzles of Wisdom). In this treatise, Galeano examines several

114 Ibid.: (şakird) benden gördüği mertebeye dek tedbīr eyleye ol mertebeye vāṣıl olıcaq banā ilām eyleye ben bir remzyazam ki kāş̧if ola [...] tā ki țarh-i iksire șāliḥ ola.

115 Ibid.: pūşīde olmaya ki eger andan qorqmasam Allāh rızāsiyçün ta lìm itmekden ben kendüm varurdum ammā ḥekìm olan imtinā ider hāâkime musāḥebet eylemekden, hākim kendü gibi hekim olmaz.

116 On the role of tağriba in medieval epistemological discussions in the Islamicate world, see Jules J. Janssens, "Experience (tajriba) in Classical Arabic Philosophy (al-FārābīAvicenna)," Quaestio, 4 (2004), p. 45-62; Miquel Forcada, "Ibn Bājja on Medicine and Medical Experience," Arabic Sciences and Philosophy, 21 (2011), p. 111-148; Dimitri Gutas, "The Empiricism of Avicenna," Oriens, 40 (2012), p. 391-436; Tzvi Langermann, "From my Notebooks: On Tajriba/Nissayon ("Experience"): Texts in Hebrew, Judeo-Arabic, and Arabic," Aleph, 14/2 (2014), p. 147-176. 
errors and fallacies in the fields of various branches of knowledge including medicine, astronomy, and mechanics, and relates first-hand episodes about the courtly and scholarly culture around the sultan. Thanks to the fascinating studies of Tzvi Langermann and Robert Morrison on Galeano and his Ta'allumot, we know that in the presence of Bāyezīd II were performed various types of operations, especially alchemical ones. ${ }^{117}$ In one such episode, an alchemist received the attention of the sultan after promising him that he can turn lead into gold. While the alchemist was conducting his operation, the rabbi Samuel Abulafia, one of the chief Jewish refugees from Spain at Bāyezìd's court, asked Galeano to pass the sultan a note from Abulafia stating that the performance of the alchemist was a fraud. Upon reading the rabbi's note Bāyezìd finally perceived his trickery. The alchemist then took his own life, drinking a lethal poison in the bathhouse. ${ }^{118}$

Mūsā Ğālīnūs is not the only contemporary who pointed to Bāyezīd II's interest in alchemy and mechanics, not to mention astronomy and astrology. Andrea Gritti (d. 1538), the famous Venetian merchant and statesman who spent much of his early life in Istanbul and had close ties with the high-ranking members of the Ottoman court, writes in one of his reports to the Venetian senate that the sultan takes delight in the arts of mechanics and alchemy. He adds that Bāyezìd is considered a very learned person in astrologia and theologia, and that he studies these disciplines ardently. ${ }^{119}$ It should also be noted that, as Tuna Artun has demonstrated, Bāyezìd II is frequently praised in the eleventh/seventeenth-century Ottoman alchemical literature as both a patron of alchemy and a practicing alchemist in his own right. ${ }^{120}$ Although Artun argues that the image of Bāyezīd as an alchemist was most probably invented in later Ottoman alchemical literature, that it was this sultan who was singled out for this purpose rather than another is most likely due to the fact his alchemical interests were witnessed in his own lifetime by several independent observers.

117 Tzvi Langermann, "From My Notebooks: A Compendium of Renaissance Science: Ta'alumot Hokmah by Moses Galeano," Aleph, 7 (2007), p. 285-318; id., "From My Notebooks: Medicine, Mechanics and Magic from Moses ben Judah Galeano's Ta'alumot Hokmah," Aleph, 9/1 (2009), p. 353-377; Robert Morrison, "An Astronomical Treatise by Mūsā Jālīnūs alias Moses Galeano," Aleph, 11/2 (2011), p. 385-413; id., "A Scholarly Intermediary between the Ottoman Empire and Renaissance Europe," Isis, 105 (2014), p. 32-57.

118 Langermann, "From My Notebooks," p. 311-314.

119 Marino Sanuto, I diarii, ed. Federico Stefani, Venezia, F. Visentini, 1881, v, p. 458.

120 Tuna Artun, "Bāyezīd-i Kimyai: Osmanli Kimya Metinlerinde Sultan II. Bāyezīd," Journal of Turkish Studies, 39 (2013), p. 181-186. 
Another contemporary testimony to Bāyezīd's learned interests comes from one Ibn al-'Ulayf (d. 926/1520), a noted poet living in Mecca, who had visited Istanbul and presented the sultan a qașida long before he composed in Mecca a chronicle eulogizing the virtues of the Ottoman dynasty generally and Bāyezīd II specifically. ${ }^{121}$ In this chronicle, he details the scholarly character of Bāyezìd II and identifies the sciences the sultan endeavored to learn. Ibn al-'Ulayf states that in addition to various branches of the religious sciences, including hadith and jurisprudence, Bāyezìd II was also interested in the science of the celestial spheres ( $i l m$ al-falak) and distinguished himself in the science of the stars ('ilm al-nuğūm) as well as geomancy ('ilm al-raml). ${ }^{122}$

It is difficult, however, to find similar remarks by contemporary "indigenous" Ottoman chroniclers and historians, who spend most of their time describing military achievements and internal political events, and rarely talk about personal and cultural aspects of court life. Nevertheless, in the works of Idrīs Bidlīsī and Kamāl Pāšāzāda, who quite frequently employ astral imagery and celestial metaphors in their narratives, it is possible to find anecdotal evidence as to the sultan's taking counsel of his munağğims before embarking upon a campaign or beginning construction of an imperial complex. ${ }^{123}$ Such anecdotes, of course, are not peculiar to his reign. However, Bāyezìd's reign is unique in the sense that his tenure is the first-and as far as we know, the last - time in Ottoman history that two different astrolabes were constructed for and presented to a sultan.

As mentioned briefly in the introduction to this study, the first of these astrolabes, now preserved at the Museum of Islamic Art in Cairo, was devised by Šukr Allāh Širwānī and presented to the sultan in the year 910/1504-1505. Although David King speculated on the name of the deviser but could not reach a decisive conclusion due to a paucity of information on Šukr Allāh Širwānī, the inscription on the astrolabe, idiosyncratically in Persian, clearly reads as "devised and constructed by Šukr Allāh, the sincere one from Shirvan

121 MS Istanbul, Süleymaniye Library, Fatih, 4357. For his qașida to the sultan see Şükran Fazlıoğlu, “Mekkeli Şair İbn el-Uleyf'in Sultan II. Bayezid'e Yazdığı Kaside," Divan: İlmî Araştırmalar, 11 (2001-2002), p. 163-181.

122 MS Istanbul, Süleymaniye Library, Fatih, 4357, f. 33b: nazara fi 'ilm al-falak wa-bara'a fi ma'rifat 'ilm al-nuğūm wa-l-raml.

123 See İbn Kemal, Tevarih-i Al-i Osman 8. Defter, ed. Ahmet Uğur, Ankara, Türk Tarih Kurumu, 1997, passim: "melik-i melek-manzar dārül-mülk-i Qosțanținden sā'at-ı sa'd ve vaqt-i meymūnda çıkub [...]"; "Hz. Pādišāh-ı hilāfet-destgāh mübārek sā'at ve fìrūz-demde maḥrūse-i Bursa'dan göçüb [...]”; "Buyurulan hișarların bināsı mühimmātını ve bennāsını ve ālātını ihżār idüb ol mübārek maṣlahata şürū' itmeǧe sā'at-ı sa'd ihtiyār idüb bünyādını qazdılar." 
(muhliş-i Širwānī)."124 A year later, another expert in astronomical devices from the lands of Rum, one al-Aḥmar al-Nuğūmī l-Rūmī, constructed an astrolabe and presented it to Bāyezìd II. Unfortunately, their names are not recorded in the voluminous register of payments as recipients of the sultan's benevolence in return for the instruments they devised. Nor is it clear what their intentions were in presenting the sultan their astrolabes. Nevertheless, that these individuals decided to devise astrolabes to present to Bāyezīd as gifts is reflective of the range of Bāyezīd's celestial and intellectual interests.

\section{Contextualizing Heavenly Pursuits at Bāyezīd's Court}

The sources adduced thus far on celestial inquiries at the court of Bāyezīd II provide strong evidence that the unprecedented extent of the cultivation of cilm al-nuğūm during his reign was intimately related to his personal intellectual aspirations. Two major questions, however, remain unaddressed. First, what might be the reasons for Bāyezĩd's genuine and documented interest in this particular branch of knowledge? Secondly and more importantly, what can we say about the implications of his deliberate attempts to cultivate ¿ilm al-nuğūm?

As regards the first question, ruling elites habitually relied on munağğims and similar experts of prognosticative sciences during the medieval and earlymodern eras. Therefore, it is difficult indeed to find Bāyezīd II's support of munağğims extraordinary. The practical benefits of employing munağğims by nature included, among other things, their service of interpreting the short and long-term political and military decisions through astrological reasoning. Besides, the royal patronage of munağğims also mattered for its significance as a political instrument, and even a powerful medium of propaganda. ${ }^{25}$ This has dual implications: on one hand, munağğims' interpretation of wordly events on astrological grounds and their sycophantic remarks for the reigning sovereign full of heavenly metaphors, touting him as the supreme one among others certified by celestial portents, endowed the ruling party with irrefutable divine significance and recognition. On the other hand, the support given for a specific group of "scientific" experts helped the sovereign easily disseminate his own image as a generous patron of knowledge. If the patron was also interested in studying the science itself, then it was even possible for him to

124 King, "Two Astrolabes," p. 447.

125 See especially Darin Hayton's book on the uses of astrological knowledge for imperial propaganda during the reign of the Holy Roman emperor Maximilian I (r. 1493-1519). 
be acclaimed by his contemporaries as a learned ruler and even the idealized philosopher-king. ${ }^{126}$

Bāyezìd II's interest in the subject itself and his arduous attempts at learning its different aspects were also not entirely uncommon, especially in the Islamicate context. The seventh/thirteenth-century Rasulid ruler of Yemen, al-Ašraf 'Umar II (r. 694/1295-696/1296), for instance, not only patronized experts in 'ilm al-nuğūm but also personally wrote at least two treatises on the subject, one on the general principles of astrology (Kitäb al-Tabșira fì 'ilm alnuğüm), and another on the use of astrolabes. ${ }^{27}$ The second work was written as an accompanying text to an actual astrolabe of al-Ašraf 'Umar's own construction. ${ }^{128}$ He even received iğăzas from his teachers for skillfully making astrolabes.

In addition to the Yemeni sultan, the most famous of all the rulers in Islamic history who showed a marked interest in learning and teaching the science of the stars is obviously Ulug Beg (d. 853/1449). He gathered at his court in Samarkand a number of experts from diyār-i Rüm and Irān-zamīn, including in the first place Ġiyāt al-Dīn Ğamšìd al-Kāšì (d. 832/1429), Qāḍizāda-i Rūmī, and 'Alī Qūščì, and utilized their efforts to conduct the observations in the newly established Samarkand observatory and teach the subject at his madrasa. Ulug Beg is documented in contemporary sources not only as a patron ruler but also as an active member of this ambitious scientific venture. In the letters of al-Kāšì to his father and the iğāza given by Qādịzāda to Fatḥ Allāh Širwānī (d. 891/1486), Ulug Beg is often pinpointed as an active participant of the classes held on astral and mathematical matters. ${ }^{129}$ The latter even eulogizes Ulug Beg as the "philosopher-king" (al-sulțān al-faylasüf) of the age.

126 For the political significance of science patronage, particularly the science of the stars, from the perspective of sovereigns' image-making in the late medieval and earlymodern context, see Robert Westman, "The Astronomer's Role in the Sixteenth Century: A Preliminary Study," History of Science, 8 (1980), p. 105-147, esp. p. 121-127.

127 Petra Schmidl, "Magic and Medicine."

128 David A. King, "The Medieval Yemeni Astrolabe in the Metropolitan Museum of Art in New York," Zeitschrift für Geschichte der arabisch-islamischen Wissenschaften, 2 (1985), p. 99-122, with addenda and corrigenda, ibid., 4 (1987/88), p. 268-269, reprinted in id., In Synchrony with the Heavens: Studies in Astronomical Timekeeping and Instrumentation in Medieval Islamic Civilization, Leiden-Boston, Brill ("Islamic philosophy and theology", 55), 2005, II, p. 615-657.

129 Mohammad Bagheri, "A Newly Found Letter of al-Kāshī on Scientific Life in Samarkand," Historia Mathematica, 24 (1997), p. 241-256; İhsan Fazlığlu, "The Samarkand MathematicalAstronomical School," Journal for the History of Arabic Science, 4/1-2 (2008), p. 3-68. 
It may be objected here that the intellectual inquiries at the court of Ulug Beg and around the Samarkand observatory were not notably astrological in orientation. It is true that the major representatives of the Samarkand school such as Qādịzāda-i Rūmī or 'Alī Qūščì were not much involved in the production of strictly astrological works, as far as the current level of research on these two individuals is concerned. Yet neither did their studies on 'ilm al-hay'a in any way entail a categorical rejection of astrological premises. Moreover, as already mentioned briefly, the end product of the observations at the Samarkand observatory, the Zĭgr-i Ulug Beg, is replete with information and data addressed to astrological purposes, especially for casting birth or yearly horoscopes. Also interesting is the fact that the activities at the Samarkand observatory were interpreted by some contemporaries, like Șầin al-Dīn Turka Iṣfahānī (d. 835/1432) — not coincidentally a patronee of that other Timurid philosopher-king, Mīrzā Iskandar, and a friend to and correspondent with Qāẹīzāda himself-, as being responsible for a renaissance of astrology. ${ }^{130}$ Last but not least, the anecdotes narrated in contemporary sources about Ulug Beg's involvement in geomantic activities in the presence of 'Alī Qūščì hint at the commonality of these preoccupations among individuals that have been strictly defined in modern historiography as enlightened scientists in the narrowest possible sense. ${ }^{131}$

We do not have conclusive evidence about whether Bāyezīd II ever aspired to cast himself as a philosopher-king and create a court reminiscent of Ulug Beg's in Samarkand, there welcoming all the major contemporary experts of the science of the stars from different regions. Yet such an impulse would not be surprising, considering the admiration for the Persianate, and specifically the Timurid, legacy in certain areas of Ottoman cultural and intellectual life at Bāyezīd's court. It is worth noting here that while most extant Ottoman taqwims prior to late-ninth/fifteenth century are in Turkish, almost all surviving ones from Bāyezìd II's reign are in Persian. Similarly, indicative of this heightened Persian cultural orientation is Bāyezīd II's active involvement in the composition of the first Ottoman dynastic histories, modeled upon specifically Timurid examples.

Indeed, the dynamics of Bāyezīd's policy to commission general histories of the Ottoman House parallel the dynamics of his sustained attempts to cultivate the science of the stars. As Halil İnalcik suggested long ago, Bāyezìd's ongoing struggle against his brother Ğem Sulțān, which soon turned into an

130 Fleischer, “Ancient Wisdom," p. 231; Melvin-Koushki, The Quest, p. 64; id., "Powers of One.”

131 Quoted from Hुwāndamīr (d. ca 942/1535) in Süheyl Ünver, Ali Kuşçi hayatı ve eserleri, Istanbul, Kenan Matbaası, 1948, p. 17. 
international crisis with the involvement of major European actors, prompted the sultan's use of history writing to influence public opinion. Moreover, the competition in the east for political and cultural supremacy against the Mamluks and various political dispensations of the post-Timurid period also necessitated a reevaluation and recasting of recent Ottoman achievements as well as Ottoman origins to accord with the claim to a universal Muslim empire. ${ }^{132}$ Next to the deployment of history writing and chancellery production for influencing public opinion, the expertise of the munağğims in giving predictive political and military guidance and in "scientifically" validating the otherwise hyperbolic ideological claims served a clear purpose during this crucial transitional period of the Ottoman polity from a relatively minor regional actor to a dominant political and cultural power of the era.

As part of these issues of legitimacy, the reign of Bāyezìd II seems to have welcomed, if not fully adopted, experimentation with the messianic and apocalyptic discourse that would become particularly popular and welldeveloped in the next two decades following the end of his reign. ${ }^{133}$ The astrological writings of Ottoman munağğims at the time, however, do not appear to be much influenced by this discourse, with the exception of the works of Mīrim Čelebī, who at times praises the sultan as the șăhib-qirān ("lord of the auspicious conjunction") and Mahdi of the end times. The real source for the articulation of such claims is rather courtly and semi-courtly historical works, exemplified by those of Idrīs Bidlīsī, Kamāl Pāšāzāda, and Firdawsī-i Ṭawīl (d. 918/1512).

Bidlīsī in his Hašt Bihišt singles out Bāyezīd as the messianic renewer (muğaddid) of the era, for his "turn" (dawla) coincides with the turn of the tenth Islamic century. ${ }^{134}$ He heavily resorts to astrological references when celebrating Bāyezīd's rule as the greatest of his age. In eight separate discourses Bidlīsī explains the underlying reasons of Bāyezīd's distinguished status, and in the sixth discourse particularly he offers purely astrological arguments. For Bidlīsī, Bāyezìd is the ideal sovereign because, according to all capable munağğims, Bāyezīd's nativity is supreme in its auspiciousness. ${ }^{135}$ According

132 İnalcık, "The Rise of Ottoman Historiography," p. 164.

133 Fleischer, "The Lawgiver as Messiah"; id., "Shadow of Shadows: Prophecy and Politics in 1530s Istanbul," International Journal of Turkish Studies, 13/1-2 (2007), p. 51-62.

134 Genç, Acem'den Rum'a: İdris-i Bidlisinin Hayatı, Tarihçiliği ve Heşt Behişt'in II. Bāyezìd Kısmı (1481-1512), p. 354-355.

135 MS Istanbul, Süleymaniye, Nuruosmaniye, 3209, f. 497b; quoted in Markiewicz, "The Crisis of Rule," p. 379: țāli-i humāyūn-i sulțān bi-ittifāq-i munağǧimān sāādatmandtarīn țālichā-i šāhān-ast. 
to Bidlīsī, Venus, the planet that signifies the prophethood and sacred law, rules the ascendant of the sultan. Other important indications related to the twelve astrological houses also imply for the sultan, as Bidlīsī maintains, nothing shorter than a steady state of health, strong natural disposition, and just rule. As Bidlīisi concludes, all of these astrological indications are the signs of Bāyezīd's preeminence over other rulers in the world. ${ }^{136}$

Apart from Bidlīsī, Kamāl Pāšāzāda also quite frequently employs in his chronicle the term sāhib-qirān, though he does not necessarily discuss the astrological reasoning underlying the title. ${ }^{137}$ Most intriguing in this context is Firdawsī-i Țawì's Quțbnāma, which he composed in 909/1503 as a lengthy history in verse of the recent Ottoman victory in Lesbos against the Venetians. Although it is clear that Firdawsī was not among the favorite littérateurs of Bāyezīd II, partly due to his lack of the necessary elite identity markers (he preferred to write in plain Turkish), he exerted all his efforts from 893/1488 onwards to catch the attention of the sultan by exploiting Bāyezīd II's intellectual interests and promoting his rule. Tellingly for our purposes here, the very first book he dedicated to the sultan was a treatise on astral magic titled Da'watnāma. ${ }^{138}$ His Quṭbnäma was written with similar intent and served to celebrate Bāyezīd's recent achievements. The real significance of the latter text derives from Firdawsi's heavy use of apocalyptic imagery with detailed references to contemporary European powers and his attempts to cast Bāyezīd as the prophesied ruler and quțb al-aqtāb (pole of poles) of the age. The notion of the "red apple" (kızl elma) that symbolizes the Ottoman millenarian desire to conquer Rome is also frequently invoked in the text. Nor is the Quțbnāma the only textual evidence for the perpetuation of the "red apple" discourse at the court of Bāyezīd II. In an anonymous dream report likely written by an individual from the class of frontier $\dot{g} \bar{a} z \bar{\imath}$-dervishes, the author states that in his dream he saw the sultan Bāyezīd sitting next to Seyyid Ġāzī, the legendary dervish warrior. Seyyid Gāzī then turned to the author and said: "Behold, I have brought Sultāan Bāyezīd ready for your service. Let him conquer westwards unto the red apple and establish the dominion of Islam."139

${ }_{136}$ Ibid.: wa-ìn ğumla-i dalăil isti'lā wa-tafawwuq-i šān-i sulțānī bar mulūk-i ğihān wa-sabab-i ruğhān-i ū bar huğasta-țălicān-i ìn dawrān.

137 İbn Kemal, Tevarih-i Al-i Osman 8. Defter, ed. Ahmet Uğur, passim.

${ }_{13} 8$ Firdawsī, Firdevsi-i Tavil ve Da'vetname'si: İnceleme, Transkripsiyon, İndeks, Faksimile ve Mikrofiş, ed. Fatma Büyükkarcı, Cambridge, Harvard Üniversitesi Yakın Doğu Dilleri ve Medeniyetleri Bölümü, 1995 .

139 MS Istanbul, Topkapı Palace Museum Archive, E. 10818; also quoted in Selahattin Tansel, "Yeni Vesikalar Karşısında Sultan İkinci Bāyezīd Hakkında Bazı Mütalaalar," Belleten, 
As these last two examples suggest, the political ambitions and cultural aspirations at the court of Bāyezīd II were not only shaped by political, ideological, and cultural rivalry within the Islamic world but also formed in relation to contemporary European powers. Although the majority of scholarship on the reign of Bāyezīd II tends to portray his stance vis-à-vis the political and cultural dynamics in Europe as anemic and idle, this was simply not the case. Especially during the first two decades of his reign when the Ğem Sulțān affair turned into an international crisis, Bāyezīd carefully engaged a busy network of spies and informants who acquainted the sultan not just with the most recent political developments but also likely with the cultural preferences at major European courts. One of these courts was clearly that of Matthias Corvinus (r. 1458-1490) with whom we know Bāyezīd II had established close relations and exchanged numerous letters based on the principles of "friendship and good neighborhood." 140 Although the content of this frequent diplomatic correspondence between Bāyezīd and Matthias Corvinus, the ideal Renaissance monarch of his time, is primarily slanted towards political and commercial issues, it is safe to assume that these communications also informed the newly enthroned Ottoman sultan about Corvinus's court culture, his patronage of astrologers, and the exemplary Biblioteca Corviniana, which thus might have served to inspire his Ottoman counterpart to undertake similar pursuits. ${ }^{141}$

Apart from the ideological implications and political instrumentality of the royal patronage for munağǧims, Bāyezīd II might have also deployed the

27/106 (1963), p. 208: Işste sana Sulțān Bāyezìdi qoşduq. Al ilet gün bāțusuna qızıl elmāya değin feth idüb İslām döşeğin döşesün.

140 Güneş Işıksel, "Friendship and the Principle of Good Neighborhood between Bāyezīd II and Matthias Corvinus," in Matthias Corvinus und seine Zeit: Europa am Übergang vom Mittelalter zur Neuzeit zwischen Wien und Konstantinopel, ed. Christian Gastgeber, Ekaterini Mitsiou and Ioan-Aurel Pop, Vienna, Verlag der Österreichischen Akademie der Wissenschaften (“Veröffentlichungen zur Byzanzforschung”, 27), 2011, p. 33-36. Also see Tayyib Gökbilbin, “Korvin Mathias (Mátyás)ın Bāyezīd ı'ye mektupları ve 1503 (909) Osmanlı-Macar muahedesinin Türkçe Metni/La traduction des letters de Korvin Mathias á Bāyezīd II et le texte turc du traité Hungaro-Ottomans de 1503 (909)," Belleten, 87 (1958), p. 369-39o.

141 On Corvinus's patronage of astrologers and interest in the cultivation of astrological knowledge see Jean-Patrice Boudet and Darin Hayton, "Matthias Corvin, János Vitéz et l'horoscope de fondation de l'Université de Pozsony en 1467," in De Bibliotheca Corviniana: Matthias Corvin, les bibliothèques princières et l'origine de l'État moderne, Actes du colloque international de Paris, 15-17 Novembre 2007, eds Jean-Francois Maillard, István Monok and Donatella Nebbiai, Budapest, Országos Széchényi Könyvtár ("Supplementum Corvinianum", 2), 2009, p. 205-213; Darin Hayton, "Expertise ex Stellis: Comets, Horoscopes, and Politics in Renaissance Hungary," Osiris, 25 (2010), p. 27-46. 
expertise of munağğims for more tangible and mundane aspects of governance such as land and maritime navigation. As briefly mentioned above, the technical know-how of the experts in the science of the stars included, besides astrological estimations, the use of instruments as well as horological, latitudinal, and longitudinal calculations. The current state of the literature on the military and maritime history of the Ottomans does not allow us to draw any firm conclusions about the possibility of interplay between the simultaneous buildup of the navy and the cultivation of the science of the stars at the court of Bayyezīd II ${ }^{142}$ However, as studies on the development of the Portuguese naval technology in the later fifteenth century have suggested, the knowledge provided by the science of the stars was widely deployed in the advancement of the nautical sciences. ${ }^{143}$ That the Ottoman tenth/sixteenth century produced figures like Muștafā b. 'Alī l-Muwaqqit (d. 979/1571) or the admiral Saydī 'Alī (d. 970/1562), who wrote prolifically on astronomical instruments and mathematical geography, indicates that similar research into the mutual relationship between the science of the stars and the art of navigation in the Ottoman context is a major desideratum. ${ }^{144}$

While space does not permit further discussion of the possible reasons and motives behind Bāyezīd II's genuine celestial interests, we may conclude unequivocally that the cultivation of the science of the stars at his court contributed in no small measure to the formation of a vibrant intellectual and scientific culture in Istanbul during the nascent stages of the city's transformation into the new imperial center of a new universal empire. Bāyezīd II's sustained attempts to support activities related to the science of the stars led to the emergence of a class of munağğims that would fill necessary cadres in

142 In her recent study, Pınar Emiralioğlu briefly mentions the works of a few experts in the science of the stars that became important for navigational purposes in the mid-sixteenthcentury Ottoman world: Pınar Emiralioğlu, Geographical Knowledge and Imperial Culture in the Early Modern Ottoman Empire, Farnham-Burlington, Ashgate ("Transculturalisms, 1400-1700"), 2014.

143 Onesimo T. Almeida, "Science during the Portuguese Maritime Discoveries: A Telling Case of Interaction between Experimenters and Theoreticians," in Science in the Spanish and Portuguese Empires, 1500-180o, eds Daniela Bleichmar, Paula De Vos, Kristin Huffine, et al., Stanford, Stanford University Press, 2008, p. 78-92.

144 One of the promising studies is Gaye Danışan Polat's ongoing project on the role of astral knowledge in tenth/sixteenth-century Ottoman nautical science. See her most recent article: Gaye Danışan Polat, "A Treatise by the 16th century Ottoman Admiral Seydi Ali Reis on Rub'-i Müceyyeb (Sine Quadrant)," in Seapower, Technology and Trade—Studies in Turkish Maritime History, eds Dejanirah Couto, Feza Günergun and Maria Pia Pedani, Istanbul, Piri Reis University Publications, 2014, p. 337-341. 
the later tenth/sixteenth century and helped to consolidate a rich canon of astronomical and astrological sources that would define the state of the art for generations to come. The scholars and texts assembled in Istanbul were instrumental both in forming and refining the contours of the scientific study of heavens in the early modern Ottoman world, and in fostering the image of Bāyezìd II as the most generous, learned, and dominant sovereign of his time, attractive as a patron to European and Persian émigrés alike.

Along similar lines but in a different context, Maria Mavroudi has convincingly shown that the cultural orientation at the court of Mehmed II was "neither East nor West, not simply because these labels did not exist in the same way they do now, but especially because he was only doing what princes before and after him often did."145 The same holds even more true for Bāyezīd II. His eclectic style in crafting his image as a cultured sovereign and his universalist intellectual aspirations - which entailed an unprecedented embrace of 'ilm alnuğum, among other royal arts - were encouraging enough to prompt various learned individuals, ranging from Leonardo da Vinci and Jewish natural philosophers from the western Mediterranean to munağğims, poets, and littérateurs from Irān-zaminn, to try their fortunes at his court.

145 Maria Mavroudi, "Translations from Greek into Arabic at the Court of Mehmed the Conqueror," in The Byzantine Court: Source of Power and Culture, ed. Ayla Ödekan, Nevra Necipoğlu and Engin Akyürek, Istanbul, Koç University Press, 2013, p. 207. 